\title{
YOUTH SPORTS IN THE NATIONAL DOCUMENTS - BETWEEN CHILDREN'S RIGHTS AND NEEDS AND THE DEVELOPMENT OF SPORTS ACCORDING TO ADULTS
}

\author{
DEPORTE INFANTIL EN LOS DOCUMENTOS NACIONALES - ENTRE \\ EL DERECHO Y LA NECESIDAD DEL NIÑO Y ORGANIZACIÓN DEL \\ DEPORTE A LA MEDIDA DE LOS ADULTOS
}

\author{
Robert Ropret \\ Faculty of Sport and Physical Education, University of Belgrade, Serbia
}

\begin{abstract}
The development of national sports systems has shown that each political orientation has a different attitude towards the issues of sports and citizens' physical activity. Notwithstanding the differences registered in the direction of the national sports system development, the fundamentals of youth sports, however, share the respect for the specificities of children growing up through sports in the present, their interests, as well as their motor, social, affective and health needs, etc. Upbringing, education, and multilayered care and protection of children and youth through sports, preservation of integrity and transfer of values in sports, as well as preservation of sports rules are the directions of actions. The regulation of this type of mass sports should start from personal and social needs and it should rely on the proven practices and the current international charters of sports and political organizations. The paper has presented international and national documents: laws, declarations, agreements, strategies, action plans, recommendations, conventions, codes, as well as the documents adopted within the academic community which consider and address the issues of the youth sports in Serbia (curricula and syllabi, textbooks).
\end{abstract}

Key words: YOUTH SPORTS / DOCUMENTS / SPORTS SYSTEM / REPUBLIC OF SERBIA

\section{INTRODUCTION}

Simultaneously with the development of sports and its increasing commercialization, the influence of politics, business, media and personal interests, the need to preserve the true values of sports, its au-

\section{EXTRACTO}

El desarrollo del sistema nacional de deporte demuestra que cada orientación política tiene una relación distinta hacia los asuntos del deporte y la actividad física de los ciudadanos. Sin embargo, sin tener en cuenta las diferencias que se notan en la orientación de desarrollo del sistema nacional del deporte, lo común para establecer el deporte de los niños y jóvenes es tener en cuenta las cosas específicas de su crecimiento a través del deporte en el momento actual, sus intereses y necesidades motrices, sociales, afectivos y de salud. Las orientaciones para actuar son la educación, adiestramiento y protección múltiple de los niños y jóvenes a través del deporte, la preservación de la integridad y transferencia de los valores deportivos, así como también la preservación de las normas deportivas. La regulación de este tipo del más masivo deporte debe empezar desde las necesidades personales y sociales y debe apoyarse en una práctica comprobada y en las cartas internacionales actuales de las organizaciones deportivas y políticas. En el trabajo se presentaron los documentos internacionales y nacionales: leyes, declaraciones, contratos, estrategias, planes de acción, recomendaciones, convenciones, códigos, así como también los documento en marco de la comunidad académica en los cuales se considera la problemática del deporte infantil en Serbia (planes y programas de estudios, manuales).

Palabras claves: DEPORTE INFANTIL/ DOCUMENTOS / SISTEMA DEL DEPORTE / REPUBLICA SERBIA tonomy, specificity, positive influence in the sphere of education and social values, the development of society is observed. In order to preserve the autonomy of sports and its essential values and at the same time 
to prevent the use of sport for purposes contrary to its objectives, many debates have been conducted and documents, declarations and regulations adopted at the international and national levels. In the political sphere, at the level of the European Union and the Council of Europe, several documents have been brought on which the documents of the Republic of Serbia are based. In the period since 2006, the Republic of Serbia has classified sports in the constitutional category, passed three Sports Laws, two strategies and action plans for their implementation, 22 rulebooks, a series of codices, conducted various actions and campaigns.

In the documents, special attention is paid to some of the most sensitive participants in sports, such as children and young people who, through sporting activities, realize their health, cultural, social and educational needs: the development of healthy and quality lives, skills and abilities, acquirie knowledge about social relations, tolerance, respect for rules, fair play, and so on. At the level of academic consideration of the phenomenon of sport of children and youth, and the preparation of personnel for meetings with the practice of sports and physical education in the $21^{\text {st }}$ century, the subject "Children's Sports" was accredited, as a compulsory course in both academic and specialist professional studies at the Faculty of Sport and Physical Education of the University of Belgrade. On this occasion, the group of authors prepared a scientific monograph "Children's sport - from practice to academic area". At the Teacher Education Faculty in Belgrade, an elective course "Education through sport" was introduced, followed by the textbook "Education through sport" by Bačanac and Radovanović (2007).

\section{CHILDREN'S SPORT AND INTERNATIONAL INITIATIVES}

At the international level, until the creation of the European Union (EU) in 1992, the European Economic Community (EEZ) did not express a particular interest in sports as a significant human activity. The documents preceding the establishment of the EU, such as the Treaty establishing the European Economic Community in Rome in 1957, as well as the Treaty on European Union, signed at Maastricht in 1992, did not contain provisions that would regulate specific EU competences in the field of sport. Only by forming the EU, documents have been adopted that have taken sport as an activity of interest for the EU and its citizens.

One of the first EU documents in the field of sport is the Amsterdam Treaty of 1997, in which the Special Declaration on Sport was adopted, recognizing and acknowledging the importance of sport for the EU and its citizens, and the social values of sport as a human activity.

The "Sports Report from Helsinki" in 1999 more precisely defined the organization and competencies in sports with emphasis on the freedom of movement of labor (professional athletes).

By the Treaty of Nice in 2000, the European Council adopted the "Declaration on the Specific Characteristics of Sport - the Social Function of Sport in Europe; a key aspect for the implementation of the common policy". According to this document, the EU should take into account in its activities the fact that sport has a social, educational and cultural function, and a special emphasis is placed on the need for special protection of youth and children in the field of sports, and the right to access sports. The declaration expresses the view that states should:

- Encourage financial and educational assistance, professional development and training and professional training of elite athletes;

- create basic conditions for training and recreation of young people, to encourage young people to engage in sports;

- control, monitor and respond to commercial transactions of minors engaged in sports.

"The White Paper on Sport", adopted by the European Union in 2007, is a comprehensive document that, among other things, emphasized that the EU will participate in activities aimed at protecting the physical and moral integrity of athletes, and especially young athletes.

The Treaty of Lisbon, signed in 2007 (entered into force in 2009), Article 165, sport, with education, vocational training and the issue of young people, has been included in an area in which the EU has the authority to take measures with a view to encouraging, coordinating and supplementing State Measures of Member States. One of these measures refers to professional staff in the implementation of sports programs (Table 1). 
Table 1. Quantitative indicators of the relationship between the number of graduated coaches and job offers in the EU (Petry et al., 2008)

\begin{tabular}{lccc}
\hline Coach level & $\begin{array}{c}\text { Number of graduates } \\
\text { (annually) }\end{array}$ & $\begin{array}{c}\text { Number of work } \\
\text { positions }\end{array}$ & Annual need \\
\hline $\begin{array}{l}\text { Master level and three years of higher } \\
\text { education }\end{array}$ & $15,000+70,000=85,000$ & 120,000 & 30,000 \\
$\begin{array}{l}\text { Two-year school and sports instructor } \\
\text { level }\end{array}$ & $15,000+100,000=115,000$ & 410,000 & 100,000 \\
Sports animator level & 150,000 & 280,000 & 70,000 \\
\hline
\end{tabular}

One of the Council of Europe directives regulates the subject of health control and prescribes the obligation that workers (including professional athletes) also have the right to health monitoring that meets the health and safety risks of their work.

An important EU document for the field of sport is also the EU Action Plan from 2000 to 2004, which was later amended by the new one. The Action Plan specifically points to the fact of the enormous impact of sports activities on the behavior of the whole public of a particular society, as well as the impact that large stars of sports competitions have on the behavior of children and youth.

Since the founding of the EU, certain non-governmental organizations through their activities and documents have made it possible to connect and exchange experiences, project realization, collect and analyse data with instructions related to sports activities. One of the organizations is the European nongovernmental sports organization (ENGSO), which in its document "Guide for children and youth sport" issues instructions for sports activities of children and youth.

At the Conference of Ministers and Senior Officials responsible for Sport and Physical Education (MINEPS), documents on the importance of physical education and sports have been adopted, as well as the need to protect young athletes from the perspective and principles established by the United Nations Convention on the Rights of the Child. The conclusions of MINEPS are binding on the participating countries of which Serbia is a member.

The conference "Sport for Development", held in Belgrade in March 2008, organized by the Ministry of
Youth and Sports and the British Council of UNICEF, was dedicated to the exchange of experiences in the area of sports of the youngest. The result of this international conference dedicated primarily to combating violence and racism in sports is the project and action "Character against violence" signed by 70 national sports federations in the form of codes of ethics: Charter of young athletes, Athletes Code of Conduct, Code of Ethics for Coaches and Physical education teachers, Code of Conduct for Parents in Sports, Code of Conduct for Sports Officials, Code of Ethics for Sports Judges and especially the Code of Ethics for Sports Judges in Youth Sports, Code of Conduct for the Viewers, Code of Sports journalist of Serbia - an addition to the Code of Journalists of Serbia (Bačanac et al., 2011, pp. 201-211)

\section{CHILDREN SPORT IN THE NATIONAL SYSTEM OF SPORTS}

Since 2001, there have been activities in Serbia aimed at identifying all actors of the sports system, and improving their business for the benefit of direct users, athletes and the sport itself. It is defined that in the scope of the sports system of the Republic of Serbia, in addition to the sports system in the narrow sense, there are also physical education and school sport, sports for all, sports sciences, engagement and role of volunteers, employees in sports organizations, scientists, as well as various associations and institutions, legislation, training centers, sports heritage... (Chart 1.) 


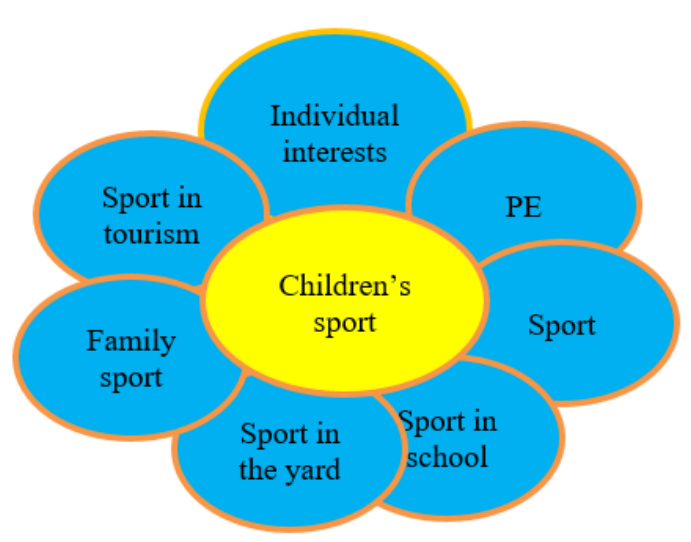

Chart 1. The environment in which children's "sports" growth takes place (Jevtić et al. 2011 p. 20)
Theoretical considerations of Children's Sports emphasize the necessity of organizing sports, starting from the needs and rights of the child and fostering the unity of motor, social and intellectual development, taking into account the positive and negative effects of sport on the child (Table 2).

Table 2 Positive and negative effects of sport on a child (Merkel, 2013)

\begin{tabular}{|c|c|}
\hline Positive effects of sport & Negative effects of sport \\
\hline \multicolumn{2}{|c|}{ Physical influence } \\
\hline 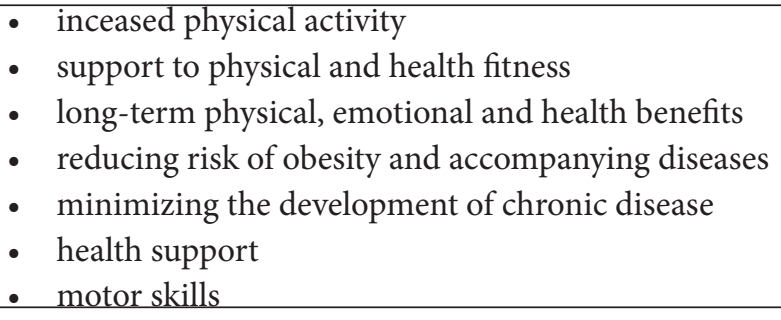 & $\begin{array}{l}\text { - injuries } \\
\text { - incompetent coaches } \\
\text { - insufficient care about safety } \\
\text { - the lack of humanistic sciences in sport } \\
\text { - } \text { abuse }\end{array}$ \\
\hline \multicolumn{2}{|c|}{ Psychical influence } \\
\hline 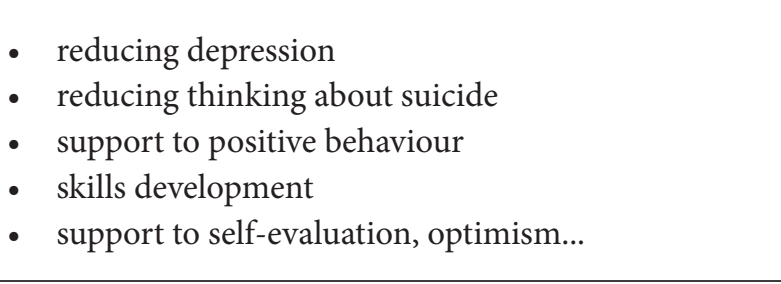 & $\begin{array}{l}\text { - increased stress and elite achievement } \\
\text { - the effects of falling off sport } \\
\text { - emphasis on competitive activity } \\
\text { - unrealistic expectaction of academic achievement } \\
\text { and career after sports } \\
\text { - abuse }\end{array}$ \\
\hline \multicolumn{2}{|c|}{ Social influence } \\
\hline $\begin{array}{l}\text { - } \text { support to social skills } \\
\text { - } \text { life long learning } \\
\text { - } \text { support to socially acceptable behaviour } \\
\text { - } \text { support to socially responsible behaviour } \\
\text { - } \text { management and leadership skills } \\
\text { - } \text { academic achievement } \\
\text { - } \quad \text { commitment and goal setting } \\
\text { - } \quad \text { character support }\end{array}$ & $\begin{array}{l}\text { - insufficient care for safety and security, equipment, } \\
\text { space for training and competition } \\
\text { - price } \\
\text { - inequality in the group (economic, ethical, racial, } \\
\text { gender) } \\
\text { - abuse }\end{array}$ \\
\hline
\end{tabular}


In order to affirm positive and minimize the negative effects of sport on the child, a rational and purposeful measure is planning, which is carried out from an individual time to a multi-year development plan, according to which, in order to achieve the unity of motor, social, intellectual development of the child through sport, it is necessary to define goals for every level of participation of the child in sport (Table 3).

Table 3 Goals of Children's sport (based on Jevtić, 2018)

\section{GOALS OF CHILDREN'S SPORT}

Goals in competitive sport

Educational goals

Social and health goals

$$
\begin{aligned}
& \text { To enable gifted and interested } \\
& \text { children to progress towards this } \\
& \text { goal }
\end{aligned}
$$

Support to educational goals of sport and benefits of its development
Excellence as a goal of children's sport

Advancement towards "Excellence in children's sport"
Support to social goals and public health, striving towards inclusion of all social goups, especially those with high level of risk for cocial acceptable-responsible behaviour
Advancement towards "Personal and social welfare and sport as a lifestyle"
The search for a better organization of certain factors in the structure of the Serbian sports system, right after the state independence of the Republic of Serbia, resulted in the creation of the "Conceptual framework of the Serbian sports system" (Jevtić, Document of the OCS, 2006). At the joint session of the Presidency of the Olympic Committee of Serbia, and representatives of sports organizations and state bodies, the Conceptual Framework for the Sports System in Serbia was harmonized. In this document, children's and youth sports are highlighted as priorities for further development. They are the same from the position of sport in the narrow sense, recognized as "gateway for elite sports" (winning medals at the OG, WC, EC) and preserving the competitiveness of the results achieved by individuals and teams of Serbia (Jevtić et al., 2010, p. 89). However, like any other concept paper, the Conceptual Framework had neither the capacity, nor the mandate to completely regulate the system of sports, so that certain issues remained to be developed through the national strategy and turned into legal solutions and by-laws!

\section{CHILDREN'S SPORT IN NATIONAL DOCUMENTS}

The initiatives of the Olympic Committee of Serbia (OCS) from 2006, outlined in the Conceptual Framework, were also aimed at the creation of new documents, primarily the integration of sports into the text of the Constitution of the Republic of Serbia, the Rulebook on national recognitions, the prizes for the development of sports, as well as establishment of the Ministry of Youth and Sports. All OCS initiatives were accepted by the state authorities, which made a step forward in creating an environment for further development of the Serbian sports system and its near and further environment. By adopting the National Sports Strategy for the period 2009-2013, and then for the period 2014-2018, the process of regulating the development strategy of the sport itself and its environment continued with the decision to establish the Ministry of Youth and Sports (MOS).

\section{The Constitution of the Republic of Serbia}

The Constitution of the Republic of Serbia from 2006 sets the sport as a constitutional category for the first time, and prescribes that the Republic of 
Serbia regulates and provides a system in the field of sports (Article 97), which defines sport as an activity of social interest. The Constitution prescribed the responsibilities of the Republic, the provinces and local authorities in promoting the value of sports. In this regard, the development of sport is determined by a number of social factors that can be grouped into two groups: (a) the factors that see the sport as a part of the social development strategy, and (b) the factors determined by the political will of the parliamentary majority. The Constitution stipulates that municipalities, through their bodies, take care of meeting the needs of citizens in the field of sports and physical culture (Article 109).

\section{Law on Sports}

Regarding physical activity and sports, in the Republic of Serbia, laws regulate two major systems the education system and the sports system.

The 2009 Law on Sports was preceded by the Law on Physical Culture in 1981, followed by the Sports laws adopted in 1996, followed by amendments from 2012 and then the adoption of the 2016 Law. Each of the laws enacted contained a status promotion mission and the organization of sports, and the latest amendments from the last Law of 2016, unlike the previous one, are:

- Health examinations for children aged 6 to 16 are free of charge;

- compulsory insurance of athletes during the performance;

- better protection of children in the sphere of mediation of managers, length and transparency of the contract.

The most important articles of this Law on Sport related to children's sports are:

- The definition of children's sports: “Children's sports is an organized form of physical exercise, or sports activities, in line with the anthropological characteristics of children's age";

- The definition of the age of a child: "Persons under the age of 16 are considered children under the terms of paragraph 4 of this article";

- Prescribing the minimum professional competence of experts for work with children. "Sports experts are persons who have appropriate higher education in the field of sports or physical culture or have been trained in accordance with Article 26, paragraph 2 and Ar- ticle 29, para. 1-4 of this Law, for performing certain professional activities in sport, unless otherwise provided by the law";

- Professional and educational work with children can only be performed by sports professionals who have appropriate higher education in the field of physical education and sports or, in addition to basic vocational training, and are especially professionally qualified for professional work with children ...";

- Predestination of the functions of the institutions of the sport system and government institutions in the implementation of the mission of children's sport, namely:

- "The competent national sports association issues to persons who have acquired the appropriate professional title in the field of sport, the work permit";

- "The Sports Association of Serbia carries out tasks that provide conditions for monitoring, development and improvement of sports recreation, children's sports, including physical education of pre-school children and school sport ...";

- Beginning in 1992, students' sports competitions are organized as a unique system for the entire territory of the Republic of Serbia, and since 1997 competitions have been administered by the Association for School Sports and Olympic Education. (Founded in 1969, is a member of the International Federation of School Sports - ISF since 2005);

- The Republic Institute of Sport is an institution that performs activities for the development of professional work and meeting professional needs in the field of sports. The activities of the Republic Institute of Sport include: 1) periodic testing, i.e. monitoring of anthropological abilities and characteristics of children, youth and adults; 15) improving the development of children and youth sports ";

- "Program costs that generate a general interest in the field of sport referred to in Article 116, paragraph 1 of this Law shall refer, as a rule, to at least $15 \%$ for activities related to sports of children";

- "The needs and interests of citizens for the realization of which are provided in the budget of local self-government units, in accordance with the law, are: 1) encouraging and creat- 
ing conditions for the improvement of sports recreation, i.e. the involvement of citizens in sports, especially children, youth, women and persons with disability; 6) physical education of children of preschool age and school sport (improvement of physical exercise, work of school sports sections and societies, municipal, city and inter-municipal school sports competitions, etc.); 14) improving the professional work of participants in the sports system from the territory of the local self-government unit and encouraging the employment of highly qualified sports professionals and elite athletes";

- "Determination of the medical fitness of pupils aged six to 14 years from paragraph 9 of this Article is performed by the selected doctor, pediatrician of the competent healthcare institution during the mandatory systematic review in accordance with the law, i.e. the doctor of sports medicine or pediatrician of the competent health institution when determining the medical fitness outside the systematic review. The costs of determining the student's medical fitness referred to in paragraph 9 of this Article shall be covered by compulsory health insurance ...".

The law precisely regulates who controls (Chapter 10) and what are the sanctions for its non-implementation (Chapter 11).

\section{Strategy for the development of sports in the Republic of Serbia for the period 2009-2013}

In this document of the Government of the Republic of Serbia, among other things, the following are defined for the national strategic goals of sport development:

- development and improvement of physical exercise of children in preschool institutions;

- Strengthening school and university sports and establishing a functional system of school and university sports competitions.

The starting point for creation of these outcomes of the Strategy is in the analyzes carried out by government and sports organizations that, among other things, have observed and concluded the following:

- Children and youth sport is in a very difficult situation;
- The number of realized weekly classes of physical education has been reduced;

- The number of gymnasiums that are equipped according to established norms is insufficient, which affects the erosion of quality and teaching standards;

- The safety and security of students is reduced, with questions about teachers' engagement issues;

- The problem of parallelism in sports competitions and the aspiration towards the elitism of some schools that rely more on students of athletes who are actively training in sports clubs in the process of school competitions;

- Increase of private initiative in recreational practice (in kindergartens, schools, local communities, to basements and shelters);

- Lack of records on the number of recreational programs, recreation facilities, as well as the level of education of instructional staff;

- Lack of norms on minimum requirements regarding equipment, apparatus and recreational exercise facilities in buildings;

- Lack of program bases for increasing the number of children involved in sports;

- The absence of a strategy for the development of sport in the housing circle (sport in the yard) that would define sports at school level, groups of schools and local self-government. Without the solution of the mentioned spatial, program, personnel and conveniences in the use of facilities, there is no implementation of the action plan.

\section{The Action Plan for the Development Strategy 2009-2013}

For implementation of the Strategy for the Development of Sport in the Republic of Serbia, an Action Plan has been defined in which the targets are set (Table 4) as follows:

- Establishing a modern sports system in preschool, school and higher education institutions;

- Promoting sports for children and youth;

- Raising the capacity of professional associations in the field of children and youth sports. 
The Action Plan envisaged the following activities:

- forming a working group for the analysis of the situation;

- analysis of the situation in preschool, school and university institutions;
- Preparation of recommendations for improving sports in these institutions;

- Call for proposals for financing sports in these institutions;

- promotion of professional associations.

Table 4 Action plan of the Ministry of Youth and Sport in the area of Children and Youth Sport

\begin{tabular}{|c|c|c|c|}
\hline OBJECTIVE & ACTIVITIES & INDICATOR & deadline \\
\hline \multirow{7}{*}{ 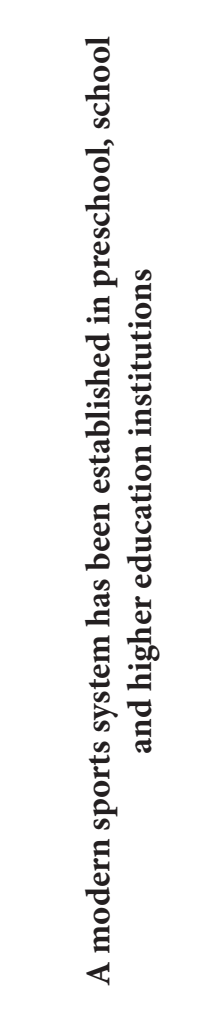 } & $\begin{array}{l}\text { Forming a working group that will deal } \\
\text { with the modernization of the sports system } \\
\text { in preschool, school and higher education } \\
\text { institutions }\end{array}$ & $\begin{array}{l}\text { A working group that will deal with the } \\
\text { modernization of the sports system in } \\
\text { preschool, school and higher education } \\
\text { institutions has been formed }\end{array}$ & 2009 \\
\hline & $\begin{array}{l}\text { Analysis of the situation in pre-school, } \\
\text { school and university sports }\end{array}$ & $\begin{array}{l}\text { Analysis of the situation in pre-school, } \\
\text { school and university sports has been done } \\
\text { and published }\end{array}$ & 2010 \\
\hline & $\begin{array}{l}\text { Analysis of sports equipment and apparatus, } \\
\text { sports fields and halls in preschool, school } \\
\text { and higher education institutions }\end{array}$ & $\begin{array}{l}\text { Established needs of preschool institutions, } \\
\text { schools and universities for sports } \\
\text { equipment and apparatus and spatial } \\
\text { capacities }\end{array}$ & 2011 \\
\hline & $\begin{array}{l}\text { Preparation of recommendations for } \\
\text { the establishment of a unique system of } \\
\text { competitions in school sport at all levels }\end{array}$ & $\begin{array}{l}\text { Recommendations have been issued for } \\
\text { the establishment of a unique system of } \\
\text { competitions in school sports at all levels }\end{array}$ & 2011 \\
\hline & $\begin{array}{l}\text { Preparation of recommendations for } \\
\text { improving the education of physical } \\
\text { education in schools }\end{array}$ & $\begin{array}{l}\text { Recommendations for improving the } \\
\text { education of physical education in schools } \\
\text { have been issued }\end{array}$ & 2011 \\
\hline & $\begin{array}{l}\text { Preparation of recommendations for } \\
\text { improving sports in preschool institutions }\end{array}$ & $\begin{array}{l}\text { recommendations for improving sports in } \\
\text { preschool institutions have been issued }\end{array}$ & 2012 \\
\hline & $\begin{array}{l}\text { Preparation of recommendations for } \\
\text { improving sport at universities }\end{array}$ & $\begin{array}{l}\text { recommendations for improving sport at } \\
\text { universities have been issued }\end{array}$ & 2012 \\
\hline \multirow{2}{*}{ 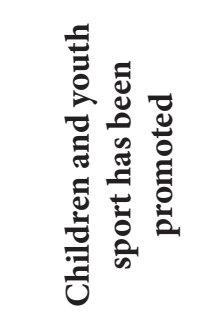 } & $\begin{array}{l}\text { Announcement of the competition for } \\
\text { financing sports promotion campaigns in } \\
\text { preschool, school and higher education } \\
\text { institutions, annually }\end{array}$ & Number of financed campaigns & 2010 \\
\hline & $\begin{array}{l}\text { Launch of the Internet site with topics of } \\
\text { sports and recreation of children and youth }\end{array}$ & $\begin{array}{l}\text { the Internet site with topics of sports and } \\
\text { recreation of children and youth has been } \\
\text { launched }\end{array}$ & 2010 \\
\hline 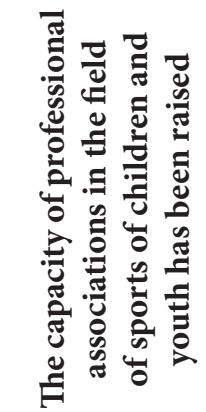 & $\begin{array}{l}\text { Preparation of recommendations for } \\
\text { improving the work of professional } \\
\text { associations in the field of children and } \\
\text { youth sports - UPFK }\end{array}$ & $\begin{array}{l}\text { recommendations of associations in the } \\
\text { field of sports of children and youth - } \\
\text { UPFK have been made }\end{array}$ & 2010 \\
\hline
\end{tabular}


Data analysis before 2009 and after 2013 shows that:

- The adoption and implementation of the Strategy for the Development of Sport in the Republic of Serbia for the period 2009-2013, with the accompanying action plan, significantly improved the situation and laid the foundation for the regulation of the sports system in the Republic;

- The measures taken in the implementation of the Strategy have yielded significant results in most strategic areas, especially in the part relating to the priorities defined by the Strategy for the Development of Sport: sport of children and youth, sports facilities and elite sport;

- work is needed to improve the realization of physical education in the field of quality, but also in the field of increasing the number of hours of physical education;

- The number of those who say that they are engaged in sports in any measure increased from $37 \%$ to $44 \%$. (once a week - $3 \%$ increase, two and more times - $15 \%$ increase).

\section{Strategy for the development of sports in the Republic of Serbia for the period 2014-2018}

The Strategy emphasizes the importance of developing physical exercise, because according to demographic data, the number of working age population in Serbia is decreasing, almost every fifth adult is obese, one third consumes cigarettes, about $40 \%$ daily or occasionally consumes alcohol, and nearly half of the population has hypertension. Those engaged in sport once a week is $10 \%$, and half of the population is not engaged in physical exercise at all. Financial resources are limited, infrastructure is inadequate and lacking, there is a lack of clear funding criteria, noncompliance with the law, disproportionate financing of recreational and competitive sports.

The strategy defines four priority areas, and the action plan defines both general and specific objectives. The strategy specifically focuses on the following priorities:

- the development of children and youth sports, including school sports;

- increasing the scope of citizens' participation in sports through the development and improvement of sports recreation;
- development and improvement of elite sports;

- development and improvement of sports infrastructure.

Compared to the previous one, the Strategy for the period 2014-2018, in the segment of the improvement of school and university sports, is significantly complemented with more specific data, outcomes and closer to defined specific goals:

- Mission - to provide the foundations of the sports system: in the part relating to sport in institutions, sport in schools and all aspects of involving children in sports activities;

- expected outcomes - that by 2018 , through the realization of this strategy, the expected outcomes will be:

$\checkmark$ greater participation of children and youth in school age in physical exercise and organized sports activities within school sports; that is, the increased number of children and youth who are organized sports activities for $15-20 \%$;

$\diamond$ greater participation of children and youth in the sport system through sports organizations and associations; that is, the increased number of children and youth who are engaged in school and university sports by $10-15 \%$.

Within the Strategy, it was pointed out that:

- All young people should receive adequate physical education and acquire basic sports skills within a regular curriculum or in extracurricular activities, thus enabling them to engage in sport every day;

- In particular girls should be provided with more opportunities to engage in sport and stay in sports, but the level and intensity of training and competitions should be adequate to their age and physical and mental condition. Therefore, those sports in which girls play a significant role in sports should be particularly supportive.

\section{Action Plan for the Development Strategy 2014-2018}

The Action Plan has been defined for the implementation of the Strategy. Within the overall goal of developing children's and youth's sports, the Action Plan defined specific goals: 
- improvement of material and technical conditions for realization of activities of school and university sports;

- increased number of sports sections and other extra-sporting activities within school and university sports;

- increased participation of pupils and students at school and university sports events (sports events and sports competitions);

- enhanced professional pedagogical work and enhanced institutional cooperation within school and university sports;

- Encouraged more important involvement of local self-government units in the implementation and improvement of school and university sports;

- promoting media monitoring and promotion of school and university sports with the aim of fostering the culture of sporting behavior, fair play, cooperation, tolerance and respect for diversity in sports grounds and in addition to them;

- Improved links between schools and organizations in the field of sports and encourage programs in sports that attract children and youth.

\section{Documents of the \\ National Education Council}

At its $78^{\text {th }}$ session, held on May 29, 2012 in Belgrade, the National Education Council decided to propose measures for improving the health of children and youth, improving the teaching of physical education through the formation of a working group and drafting a document entitled "Proposal for Measures to Improve teaching physical education ". The document defines the following measures:

- It is necessary to establish a system for monitoring physical development and development of motor skills of students within the Education system throughout the whole of Serbia (establishing a database, analyzing the situation and taking measures to improve the health of pupils - a project is underway jointly initiated by the Institute for Evaluating the Quality of Education and Upbringing and Faculty of Sport and Physical Education in Belgrade);

- Take measures to unify the spatial technical conditions for the realization of physical education classes throughout the whole of Serbia in accordance with the adopted Standards for the Implementation of Teaching and Standards of Student Achievement;

- Teaching of physical education is, because of its complexity, to a large extent limited to the application of consistently carried out individualization. For this reason, the realization of teaching in a differentiated form is proposed, which would give a higher level of student achievement. It is also necessary to revitalize additional and additional teaching in physical education. Supplementary teaching would include students with a lower level of motor skills and students requiring special physical exercise (corrective gymnastics). Additional classes would include students specially talented for sports and other motor activities. As in other subjects, so in physical education it is necessary to create conditions for working with talented children, but in the younger age. The basic requirement is how to recognize talented children and how to organize work with them. In the younger school age, identification of talented children and work with them is absent;

- All activities related to physical or sports activities of students (school sport) are a powerful tool in providing a preventive role in the protection of children / pupils against aberrant behavior and violence;

- Introduce all sports school competitions into the Ministry of Education system and the school calendar for the current year (as is the case with competitions in other subjects);

- It is recommended that physical education in the younger classes $\left(3^{\text {rd }}\right.$ and $\left.4^{\text {th }}\right)$ is carried out by teachers of physical education in all schools where this is possible (it is necessary to be envisaged by the Law on the basics of the education system), and in schools in which there are no conditions for this, class teachers would do it with the professional-instructive work of $\mathrm{PE}$ teachers (this recommendation is derived from a large number of research that dealt with the problems of achievement in the teaching of physical education in younger classes);

- Enable the same conditions for teaching physical education in classes with younger and older students (if there are conditions, enable physical education of younger students to be taught in the school gymnasium); 
- A proposal to reintroduce pedagogical supervision;

- Due to the expressed lack of regular physical activity of children and pupils, a number of projects that encourage self-organization and organized exercise of students, such as: weekend sports in the school yard, summer and winter break in the school yard, the SPRET model for students, sports and recreational camps of students and the like.

- Exercise activities and school competitions can be promoted by engaging teachers of physical education who would exclusively deal with the organization of sports and recreational activities of pupils in their spare time (during working days and weekends), as well as organizing programs for sports and recreational activities of pupils in the school facilities, during winter and summer breaks;

- Enable the opening and use of school halls, during winter and summer holidays, for planned supplementary and additional classes and freely selected pupils' sports activities;

- In secondary school, innovate the physical education program in order to enable solving of physical education tasks in accordance with the objective conditions for teaching. In this way, teachers would be able to select the physical training content themselves in accordance with the students' needs and abilities;

- Together with the Ministry of Youth and Sports and the Ministry of Health, find a solution for budget-financed teaching of elective physical education for students at state universities.

\section{Rulebooks of the Ministry of Youth and Sports}

In addition to the Law on Sports, the Strategy for the Development of Sport and the Action Plan, the Ministry of Youth and Sports has issued 22 by-laws / rulebooks. For the field of children's sports, the following are of direct importance:

- Rulebook on determining the health competence of athletes for performing sports activities and participation in sports competitions ("Official Gazette of the RS", No. 15/12);

- Rulebook on conditions for performing sports activities ("Official Gazette of the RS", No. 63/13);
- Rulebook on sports branches of special importance for the Republic of Serbia ("Official Gazette of the Republic of Serbia”, No. 72/11 and 25/13);

- Rulebook on Supervision of Professional Work in the Field of Sport ("Official Gazette of the RS”, No. 92/11);

- Rulebook on the permission for the work of sports experts ("Official Gazette of the RS", No. 7/13);

- Rulebook on Detailed Conditions for Performing Sports Activities ("Official Gazette of the RS”, No. 17/13);

- Decision on the establishment of the National Council for the Fight against Violence and Misbehavior of Viewers at Sports Events ("Official Gazette of the RS", No. 65/11 and 100/12).

The adoption of the new Law on Sports (2016) stipulated that by the beginning of 2018 the existing regulations would be harmonized with the new Law.

\section{TEACHING PROGRAMS OF ACCREDITED HIGHER EDUCATION INSTITUTIONS}

Since 2001, at the Faculty of Sport and Physical Education of the University of Belgrade, the course "Children's Sports" has been established in the accredited program of academic and professional studies. With the course program, the textbook "Children's Sports - from Practice to the Academic Area" is harmonized (by Jevtić B., Radojević J., Juhas I, and Ropret R., 2010). The excerpt from the Review describes in more detail the professional (practice) and academic capacity of the children's sports field, with the reviewers quoting the following (Jovanović, S, Radovanović, I): $\quad$ "The book "Children's Sports from Practice to the Academic Area", divided into two parts (Children's Sports Theory and Practice Examples of Children's Sports), contains 18 chapters as an expert and scientific contribution of 22 authors from the Faculty of Sport and Physical Education and 3 authors from other institutions of Serbia. The book makes a unique and coherent publication covering the academic area that studies the child and his physical, mental, intellectual, social development through sports. It is a result of many years of author's work on the problems 
and area of the "Children's Sports" area. With a sufficient number of auto-citations, the authors have shown that they are reference and competent to deal with this complex theoretical and practical space. The strength of the book is a clear emphasis on the place and importance of sports in the child's upbringing and the place of sports in accepting the universal value framework, as well as the values of society and the individual. Unlike most cognitive areas, the children's sport has reached the framework of the system of science that makes up this educational area - from the idea, through the subject, to the sense and values to which documents belong (the national strategy and action plan)."

At the Teacher Education Faculty in Belgrade, the subject "Education through sport" was established, within which the book "Education through sport" was published (Bačanac and Radovanović, 2007).

\section{DOCUMENTS ON RIGHTS OF A CHILD AND HUMANE GROWTH THROUGH SPORT}

At the end of the 1970s, the American National Association for Sport and Physical Education passed the Bill of the Rights of Young Athletes. The Bill contains 10 elementary rights (the eleventh, about protection against doping, was added by Dr. Bačanac Lj., A psychologist at the Republic Institute for Sport). The Charter may serve as a basic guideline for directing further development of youth sports. It presents a summary of the main philosophical positions and goals of children's and youth sports.

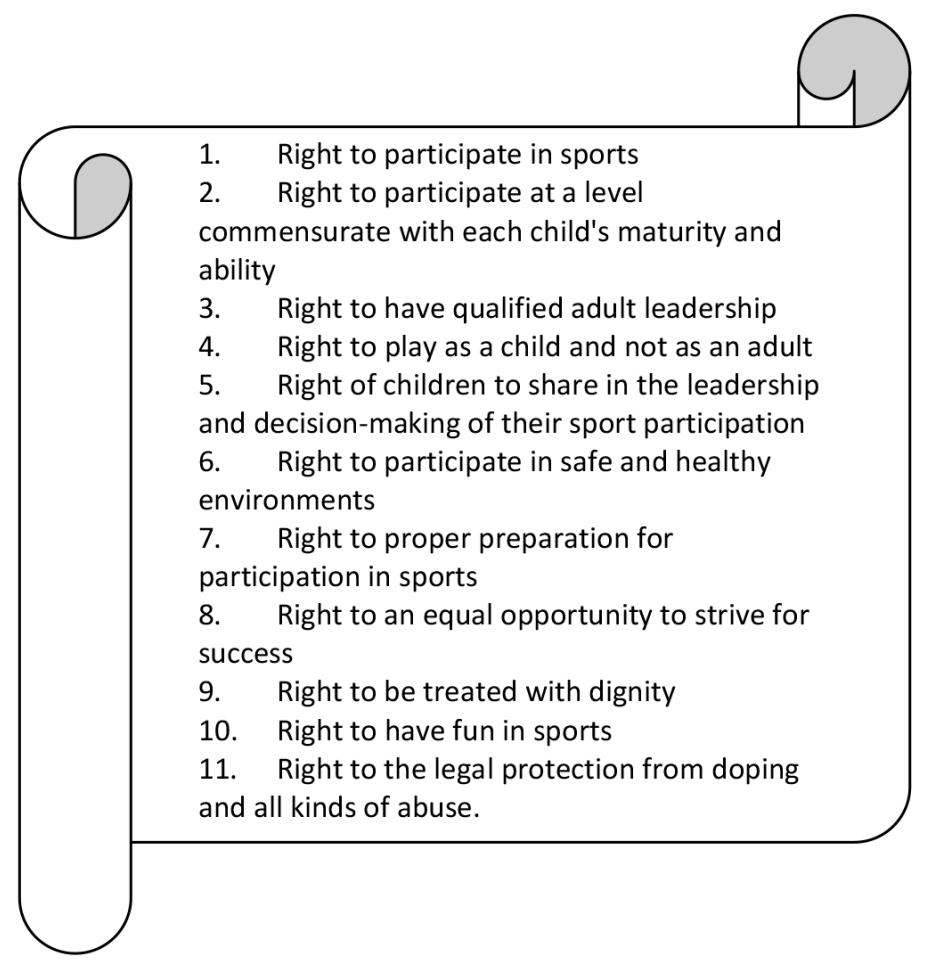

Picture 1. Bill of Rights for Young Athletes (Bačanac et al., 2011, p. 201)

Apart from normative documents, the children's sports are discussed from different perspectives, from which at least three values are derived (Jevtić et al, 2010, p. 19):

- "Sport for children" - a point of view that emphasizes that sport should be at the service of a child;
- "Children for sport" - the direction of children and youth towards sports, in which there exists a model of early identification of talents and their inclusion in national programs of superior sports achievement, and

- "Optimal sporting achievement in the interest of child development" - this is an attitude 
that insists on respecting the legitimacy of the child's biological, social and psycho-motor development. It directs it towards a sporting or physical activity aimed at securing the "human world of children's sport".

Regardless of the viewpoint or the organized system, in European processes, the emphasized impera- tive is the need to establish the "human world of children's sport", which, as the basis of the system, provides the humanity of the youth sport.

The future of children's sports can be realized through recommendations from the "aspect" of the ministry, parents and coaches (Table 5).

Table 5. Recommendations for the success of children's sports ( Merkel, 2013)

\begin{tabular}{|c|c|c|}
\hline Society & Parents & Coaches \\
\hline $\begin{array}{l}\text { - Training of coaches } \\
\text { - Safety and safety of children } \\
\text { - } \text { Financing and budget } \\
\text { - } \text { area } \\
\text { - Supporting policies and procedures } \\
\text { - Support to the participation of } \\
\text { neglected groups } \\
\text { - Increased availability of space, } \\
\text { - } \text { equipment and equipment } \\
\text { - Mandatory principles }\end{array}$ & $\begin{array}{l}\text { Parental support and focus on the } \\
\text { benefits of growing up through } \\
\text { sports and entertainment, not on } \\
\text { winning } \\
\text { - Orientation towards skills } \\
\text { acquisition } \\
\text { - Support during training and } \\
\text { competitions } \\
\text { - Promoting desirable behavior, } \\
\text { heartiness, accuracy, nutrition, } \\
\text { hydration ... }\end{array}$ & $\begin{array}{l}\text { - Emphasis on play and entertainment } \\
\text { - } \quad \text { So imperative of victory } \\
\text { - } \quad \text { Greater focus on physical activity and } \\
\text { learning in relation to skills finalization } \\
\text { - Competence for working with children } \\
\text { - Instructions, methods and techniques are } \\
\text { appropriate for the child } \\
\text { - Knowledge of sport and rules } \\
\text { - Knowledge about principles of training, } \\
\text { motor skills, growth and development, } \\
\text { nutrition, dynamics of development of } \\
\text { skills, fitness, results, safety, injuries } \\
\text { - Analysis of the training situation, } \\
\text { identification of risk factors, protection } \\
\text { measures, first aid }\end{array}$ \\
\hline
\end{tabular}

One way to secure the "humane world of children's sports" is to build a theory based on which the practice of quality physical and sports activities of children and youth would rely on. In other words, experts and scientists need to make an effort to identify and address the problems of children's and youth sports, within the theory of sports and sports training, as well as the theory of all sports branches. Such a theoretical approach, from which practice would follow, would enable avoiding situation in which the forms of work with adults would be transferred to the workplace with children and young people, thus causing damage, primarily to the child and the young person, and then to the development of sport. The fact is that youth sport is the basis of senior sports and therefore it should be organized differently, adapted to the nature, needs and possibilities of children, and not as before, according to the standards and models of adult sports.

For the needs of the European Commission, in 2008, the research (analysis) of the situation in children's sport in the $27 \mathrm{EU}$ Member States was carried out (European Commission, 2008). The research describes the complexity of the space of the children's sports theory, which identifies the basic elements, instructions and direction of improving children's sports through activities and programs:

- The complexity of the training system for children and youth is emphasized (organization, financing, management, specialized training centers, the relation between amateur and professional sports, place and role of the club...);

- The existence of qualitative criteria for accreditation of the club, sports center, new organizational structure of clubs adapted to the needs of children's and youth sport was suggested. Qualitative criteria are divided into two groups: criteria related to the training system for children and youth (number of athletes in training and within the group, equipment and apparatus, training area, scope of training, etc.), and criteria related to the integral development of young athletes (education, protection of young athletes, competence of engaged individuals ...);

- the existence of legal norms and documents, as well as the plans of EU member states to sup- 
plement and amend the existing regulations in the field of children's and youth sports;

- social significance, as well as financing programs and sports centers, as well as the development and implementation of qualitative criteria;

- education of athletes, including the duration of schooling, specialized schools and departments, sports links and professional careers, scholarships, ethical standards, programs after the end of a sports career;

- health care and protection, medical monitoring, recovery, health and eating habits, injuries and diseases;

- protection of minors;

- prevention in doping;

- rights from contractual relations, relations of athletes and clubs, freedom of athletes' movement, compensation for the first training club, social and pension insurance, place of residence of an athlete;

- training, duration and frequency of training in relation to age (6-8 years of age $=240$ hours / year, 9-11 years of age $=240-400$ hours $/$ year, $12-15$ years of age $=800$ hours $/$ year; $15-18$ years of age - up to 1100 hours / year);

- Technology of joint training of boys and girls;

- profession and permanent training of coaches;

- manuals for coaches with chapters of training of children and youth;

- training of persons with special needs, regulatory mechanisms, promotion, inclusion and

- sports schools.

\section{Codices}

In addition to laws and by-laws, the following are important for the field of child sports: Code of Ethics, Charter of the rights of young athletes, Code of Conduct for Athletes, Ethics Code of Coaches and PE Teachers, Code of Conduct for Parents in Sports, Code of Conduct for Sports Officials, Code of Ethics for Sports Judges, Ethics Code of Sports Judges in Youth Sports, Code of Conduct for the Viewers, Code of Sports Journalists of Serbia - Addendum to the Code of Journalists of Serbia

\section{Actions and campaigns}

Different non-governmental organizations carry out actions and campaigns aimed at improving the values of children's sports:

- Sport against violence, drugs, smoking;

- Character against violence;

- Sport in schools.

\section{COACHES FOR WORK IN CHILDREN SPORT}

European occupational standards define the "sports coach" by the role of the sports coach and his / her competences (Jevtić et al., 2010, p. 25). In this regard, the work of the coach can be directed towards:

- As many participants in the sport (participatory sport), or

- Building a sports result (a competitive sport in a full sense).

The coach who is oriented towards a larger number of participants, works with beginners for programs that are not motor-complex and that are acceptable to everyone (children, adolescents, adults). Goal-oriented coach works with gifted athletes, builds the prerequisites for elite sporting results (kids, adolescents, adults). To have some of the training programs for coaches (at the university and / or through the sport system, both formal and informal) with characteristics of a European model, it must, as a result, qualify a competent coach. Competence is guaranteed by training for achieving high quality of work of both groups of coaches (Radojević and Jevtić, 2002).

Each new level of competence is ensured by further training of coaches, which stimulates professional and scientific curiosity, connects and applies acquired knowledge, analyses and improves practice, and uses facts in an optimal, purposeful and scientific way. These are great demands, since most of the facts about man and his "sports being" are learned by scientific method and best practice analysis, and that the training takes place during many years of learning and work.

In order to build a competent coach, European professional associations and employers' associations created a convention defining a European model of quality of coaches, which contains the following requirements (Petru, Froberg, Madela, and Tokarski, 2008):

- The coach plays a major role in acquiring sports experience of athletes of all ages and levels;

- To fulfil his / her role, the coach must have appropriate competence and continuous improvement (training). In doing so, competence 
must be established in relation to the group of people with whom he / she works;

- Coaches take care of the good condition of athletes during the development of their abilities;

- Coaches must respect the rights, dignity, value of each athlete, and that they behave equally, regardless of gender, ethnic origin, religion or political commitment;

- Coaches work openly and cooperatively with all subjects and are responsible for the personal well and good results of each athlete;

- Coaches conduct high-standard training based on scientific facts and current experience of training technology;

- Scientific principles should be applied at each level of work of coaches;

- The responsibility and professional competence of the coach is built from the initial to the highest level;

- All coaches must have a qualification verified by the competent sports federation and a competent national body designated by law;

- The framework for recognizing coaching competence and qualifications is given by the European Coaches Association;

- Mechanisms of previous education and current competence should be defined as soon as possible and give criteria for their recognition and

- Establish a licensing system for coaches that will be internationally recognized and valid.

\section{CONCLUSION}

Sports, and especially children's sport, must be nurtured as a powerful means of support to growing up, developing life skills and habits. It is part of a modern civilization, its functions are focused on the health and development of social, cultural and educational aspects of all members of society, especially children.

It is indisputable that the EU, its members, as well as the Republic of Serbia, are working on improving and adapting the value of sports to the specific needs of children. In the period from 2000, activities that recognize all actors and actors of the sports system have been started in order to perfect their business for the benefit of direct users, primarily children athletes, as well as the organization and functioning of sports. In concrete activities, it started from the international documents of sports and political organizations as well as the academic community, in order to eventually adopt the national documents presented in the Republic of Serbia through the Constitution and Legislation (Laws on Sport), the state strategy for sport development (2009 and 2014), action plans (plans for implementation of strategies in 2009 and 2013), regulations, codices, as well as the decision of the National Education Council.

The Academic Community of Physical Education has given an incentive to the human world of childhood growth through sports by including in its accredited study programs the subject of "Children's Sports". As it was proper, for this subject a textbook was prepared - a scientific monograph "Children's Sports from Practice to the Academic Area".

The goal of the joint activities of the system of sports, the state and the academic community of physical education and sports is to provide the humane world of children's sports - respecting its specificity and principles of work, to which adult forms of work cannot be transferred. A vision was defined, goals, tasks and outcomes were appointed, documents were adopted, accompanying written materials related to the subjects and problems of children's sports were prepared. With such cognitive approach the foundations of children's sports have been created that should be developed into the principles of professional work in the unique educational area Children's Sports and which should provide:

- Understanding the need and ensuring the rights of the child, the adoption of professional and legal norms and documents in the field of children's sports;

- Specificity of organizing children's sport as a subsystem of sport and education, as well as individual interests of the child with elements, such as management, financing, organization of clubs, training centres;

- Forming qualitative criteria for (a) organizing a training system, (b) developing young athletes;

- Health care and protection, their continuous monitoring, eating habits, prevention of injuries;

- Prevention of doping, protection of minors from all forms of violence and abuse;

- Respecting the principle of training in accordance with the biological, chronological and 
sports "age" of the child (scope, intensity of training, joint training of girls and boys);

- Education of athletes, organization of specialized schools and departments, connection between sports and professional careers, scholarships, programs after the end of a career;

- Regulation of rights of young athletes, rights from the contractual relationship of athletes - club - association, right to mobility, compensation for the first club, social and pension insurance;

\section{REFERENCES}

1. Bačanac Lj, Petrović N, i Manojlović N. (2010). Psihološke osnove treniranja mladih sportista. [Psychological basis of training of young athletes. In Serbian]. Beograd: Republički zavod za sport.

2. Bačanac, Lj. i Radovanović, I. (2005). Vaspitanje kroz sport. [Education through sports. In Serbian]. Beograd: Učiteljski fakultet.

3. Dečiji sport od prakse do akademske oblasti (2010). [Childrens sport from practice to academic area. In Serbian]. Fakultet sporta i fizičkog vaspitanja, Beograd.

4. Jevtić, B., Radojević, J., Juhas, I. i Ropret, R. (2010) Dečiji sport od prakse do akademske oblasti. [Childrens sport from practice to academic area. In Serbian]. U B. Jevtić, J. Radojević, I. Juhas, R. Ropret Ed „Dečiji sport od prakse do akademske oblasti” srt. 19-27. Beograd: Fakultet sporta i fizičkog vaspitanja.

5. Jevtić, B. (2018). Olimpizam i studentski sport. [Olympism and student sport. In serbian]. U E. Kastratovic (ed): U duhu Olimpizma (str . 15-47). Beograd: Fakultet za biznis i pravo.

6. Merkel, L.D. (2013). Youth sport: positive and negative impact on young athletes. Open Access Journal of Sports Medicine: 4 151-160

7. Petru K, Froberg K, Madela A, \& Tokarski W. (2008). Higher education in sport in Europe. UK: Mayer \& Mayer sport.
- Education and training programs for coaches;

- Work program with children with disabilities and children with special needs in educational work.

Affirmation of children's sport is the best way of functioning of the $21^{\text {st }}$ century society for the integral development of children, their positive biological, social, affective and intellectual development, for accepting values such as effort, respect, solidarity, trust, coexistence and social cohesion, ethnical, gender, and religious tolerance.

\section{Documents:}

1. European Commission (2008). Study on training of young athletes/women in Europe. INEUM consulting, June 2008.

2. The Helsinki Report on Sport - COM (1999) 644, Report from the Commission to the European Council with a view to safeguarding current sports structures and maintaining the social function of sportwithintheCommunity framework,1.12.1999., Retrieved 1.2.2018. from http://eurlex.europa.eu/LexUriServ/LexUriServ. do?uri=COM:1999:0644:FIN: EN:PDF

3. Treaty of Amsterdam, OJ C 340, 10.11.1997., The Declaration on Sport, Retrieved 1.2.2018. from http://europa.eu.int/eurlex/lex/en/ treaties/ dat/11997D/htm/11997D.html

4. Treaty of Lisbon, OJ C 306, 17.12.2007, Retrieved 1.2.2018. from https://eur-lex.europa.eu/legalcontent/EN/ALL/?uri=OJ\%3AC\%3A2007\%3A30 $6 \% 3$ ATOC

5. Treaty of Nice, OJ C 80, 10.3.2001, Retrieved 1.2.2018. from https://eur-lex.europa.eu/legalcontent/EN/ALL/?uri=OJ\%3AC\%3A2001\%3A08 $0 \% 3 \mathrm{ATOC}$

6. White paper on sport, Commission of the European Communities, Brussel, 11.7.2007, COM (2007) 391 Final, Retrieved 1.2.2018. from http://eur-lex.europa.eu/legal-content/EN/ TXT/?uri=CELEX\%3A52007DC0391

7. Akcioni plan razvoja sporta 2014-2018. (2015). [Sport Development Action Plan 2014-2018. In Serbian]. Sl. glasnik RS”, br. 1/2015). 
8. Zakon o sportu (2016). [Law on Sports. In Serbian]. Sl. glasnik RS", br. 10/2016).

9. Zakon o sportu (2011). [Law on Sports. In Serbian]. Sl. glasnik RS” br. 24/11).

10. Zakon o sportu (1996). [Law on Sports. In Serbian]. Sl. glasnik RS" br. 52/96).

11. Jevtić, B. (2006). Idejni okvir novog sistema sporta Republike Srbije. Zajednička sednica činilaca sistema sporta Srbije. [The conceptual framework of the new sports system of the Republic of Serbia. Joint session of the members of the Serbian sports system. In Serbian]. Beograd: Olimpijski komitet Srbije.

12. Ministarstvo omladine i sporta (2009). Akcioni plan za sprovođenje Nacionalne Strategije razvoja sporta u Republici Srbiji (2009 - 2013). [Action Plan for the Implementation of the National Strategy for the Development of Sport in the Republic of Serbia 2009-2013. In Serbian]. Dostupno 1.2.2018. na www.mos.gov.rs.

13. Nacionalni prosveni savet Republike Srbije (2012). Predlog mera za unapređivanje nastave fizičkog vaspitanja [Proposal measures for improving the teaching of physical education. In Serbian]. (dostupno 15.1.2018. na http://www. nps.gov.rs/).

14. Neobjavljeni materijali Jugoslovenskog olimpijskog komiteta (Materijal dr Madić Dejana - sa 11. sastanka radne grupe Evropskih nevladinih sportskih organizacija - ENGSO, 2001).

15. Odluka o obrazovanju Nacionalnog saveta za borbu protiv nasilja i nedoličnog ponašanja gledalaca na sportskim priredbama (2012). [Decision on the Education of the National Council for the Fight against Violence and Misbehavior of Viewers at Sports Events. In Serbian]. Službeni glasnik RS", br. 65/11 i 100/12.

16. Pravilnik o bližim uslovima za obavljanje sportskih aktivnosti i sportskih delatnosti (2013). [Rulebook on Detailed Conditions for Performing Sports Activities and Sports Activities. In Serbian]. Službeni glasnik RS, broj 17/13).
17. Pravilnik o dozvoli za rad sportskih stručnjaka (2013). [Rulebook on the license for the work of sports experts. In Serbian]. Službeni glasnik RS", br. $7 / 13$.

18. Pravilnik o nadzoru nad stručnim radom $\mathrm{u}$ oblasti sporta (2011). [Rulebook on Supervision of Professional Work in the Field of Sport. In serbian], Službeni glasnik RS”, br. 92/11.

19. Pravilnik o sportskim granama od posebnog značaja za Republiku Srbiju (2011, 2013). [Rulebook on sports branches of special importance for the Republic of Serbia. In Serbian]. Službeni glasnik RS. 72/11 i 25/13).

20. Pravilnik o uslovima za obavljanje sportskih delatnosti (2013). [Rulebook on conditions for performing sports activities. In Serbian]. Službeni glasnik RS, br. 63/13.

21. Pravilnik o utvrđivanju zdravstvene sposobnosti sportista za obavljanje sportskih aktivnosti i učestvovanje na sportskim takmičenjima (2012). [Rulebook on determining the health competence of athletes for performing sporting activities and participation in sports competitions. In Serbian]. Službeni glasnik RS: 15/12.

22. Republički zavod za sport (2010). Analiza realizacije akcionog plana strategije razvoja sporta republike Srbije. [Analysis of the implementation of the action plan of the strategy of sport development of the Republic of Serbia. In Serbian]. Dostupno 25.2.2018 na http://www.rzsport.gov. rs/download/file/EVALUACIJA\%20STRATEGIJE\%202009-2010\%20ex.pdf)

23. Strategija razvoja sporta 2014-2018 (2015). [Sport Development Strategy 2014-2018. In Serbian]. Sl. glasnik RS: 1/2015.

24. Strategija razvoja sporta u republici Srbiji za period 2009-2013 (2008). [Strategy for the development of sports in the Republic of Serbia for the period 2009-2013. In Serbian]. Sl. glasnik RS: $110 / 2008$.

25. Ustav Republike Srbije (2006). [Constitution of the Republic of Serbia. In Serbian]. Sl. glasnik RS: 98/2006. 


\title{
ДЕЧИЈИ СПОРТ У НАЦИОНАЛНИМ ДОКУМЕНТИМА - ИЗМЕБУ ПРАВА И ПОТРЕБА ДЕТЕТА И УРЕБЕЊА СПОРТА ПО МЕРИ ОДРАСЛИХ
}

\author{
Роберт Ропрет \\ Факултет спорта и физичког васпитања, Универзитет у Београду, Србија
}

\begin{abstract}
Сажетак
Развој националних система спорта показује да сваки политички правац има различит однос према питањима спорта и физичке активности грађана. Без обзира на разлике које се региструју у правцу изградње националног система спорта, ипак, заједничко за поставке спорта деце и младих је уважавање специфичности њиховог одрастања кроз спорт у садашњем времену, интересовања, моторичке, социјалне, афективне и здравствене потребе.... Правци деловања су васпитање, образовање и вишестрана заштита деце и младих кроз спорт, очување интегритета и трансфер спортских вредности, као и очување спортских правила. Регулисање овог, најмасовнијег вида спорта треба да крене од личних и друштвених потреба и треба да се ослања на проверену праксу и актуелне међународне повеље спортских и политичких организација. У раду су представљена међународна и национална документа: закони, декларације, уговори, стратегије, акциони планови, препоруке, конвенције, кодекси, као и документа у оквиру академске заједнице којима се разматра проблематика дечијег спорта у Србији (наставни планови и програми, уџбеници).
\end{abstract}

КљУчне речи: ДЕЧИЈИ СПОРТ / ДОКУМЕНТА / СИСТЕМ СПОРТА / РЕПУБЛИКА СРБИЈА

\section{УВОД}

Упоредо са развојем спорта и његове све веће комерцијализације, уплива политике, бизниса, медија и личних интереса, уочена је потреба за очувањем правих вредности спорта, његове аутономије, специфичности (посебности), позитивног утицаја у сфери образовања и социјалних вредност, развоја друштва... У циљу очувања аутономије спорта и његових суштинских вредности, и истовременог спречавања коришћења спорта у сврхе, супротне његовим циљевима, воде се многе расправе и доносе документи, декларације и прописи на међународном и националном нивоу. У политичкој сфери, на нивоу Европске уније и Савета Европе донето је неколико докумената на којима се темеље и документи Републике Србије. У периоду од 2006. године Република Србија је сврстала спорт у уставну категорију, донела три Закона о спорту, две стратегије и акциона плана за њихово остварење, 22 правилника, низ кодекса, спровела различите акције и кампање.

У документима се нарочита пажња обраћа на део најосетљивијих учесника у спорту, а то су деца и млади који кроз бављење спортом остварују своје здравствене, културне, социјалне и образовне потребе: развој здравог и квалитетног живота, развој вештина и способности, стицање сазнања о социјалним односима, толеранцији, поштовању правила, фер-плеја и др. На нивоу академског разматрања феномена спорта деце и младих, и припреме кадрова за сусрете са праксом спорта и физичког васпитања у 21. веку, акредитован је предмет „Дечији спорт“, као обавезан предмет како на академским, тако и на струковним студијама Факултета спорта и физичког васпитања Универзитета у Београду. Поводом тога, група аутора је приредила научну монографију „Дечији спорт - од праксе до 
академске области“. На Учитељском факултету у Београду уведен је изборни предмет „Васпитањем кроз спорт“ кога прати и уџбеник «Васпитање кроз спорт» аутора Бачанац и Радовановић (2007).

\section{ДЕЧИЈИ СПОРТ И МЕЂУНАРДНЕ ИНИЦИЈАТИВЕ}

На међународном нивоу, до настанка Европске Уније (ЕУ) 1992. године, Европска економска заједница (ЕЕ3) није изражавала посебно интересовање према спорту као значајној људској делатности. Документа која су претходила оснивању ЕУ, као што су Споразум о оснивању Европске економске заједнице у Риму 1957. године као и Уговор о Европској унији, потписан у Мастрихту 1992. године, нису садржавали одредбе којима би биле регулисане посебне надлежности ЕУ у области спорта. Тек формирањем ЕУ донети су документи који су уважили спорт као делатност од интереса за ЕУ и њене грађане.

Један од првих докумената ЕУ у области спорта је Амстердамски уговор из 1997. године у којем је донета посебна Декларација о спорту, чиме је препознат и уважен значај спорта за ЕУ и њене грађане, и друштвене вредности спорта као људске делатности.

„Извештај о спорту из Хелсинкија “ 1999. године прецизније је дефинисао организацију и надлежности у спорту са нагласком на слободу кретања радне снаге (професионланих спортиста).

Уговором из Нице 2000. године Европски савет је усвојио „Декларацију о специфичним карак- теристикама спорта - социјална функција спорта у Европи; кључни аспект за имплементацију заједничке политике". Према овом документу ЕУ би требало у својим активностима да узима у обзир чињеницу да спорт има социјалну, образовну и културну функцију, а посебно је истакнута потреба за посебном заштитом омладине и деце која се баве спортом, и право на доступност спорта. У декларацији је изражен став да државе треба да:

- подстакну новчане накнаде и помоћ за образовање, стручно усавршавање и обучавање и професионално оспособљавање врхунских спортиста;

- стварају основне услове за тренинг и рекреацију младих, да подстичу младе да се баве спортом;

- контролишу, прате и реагују у вези са комерцијалним трансакцијама малолетника који се баве спортом.

“Бела књига о спорту” коју је Европска унија усвојила 2007. године, представља свеобухватни документ у којем је, између осталог, наглашено да ће ЕУ учествовати у активностима које имају за циљ заштиту физичког и моралног интегритета спортиста, а поготово младих спортиста.

Уговором из Лисабона, потписаним 2007. године (ступио на снагу 2009), чланом 165 , спорт, уз образовање, стручно оспособљавање и питање младих особа, уврштен је у подручје у којем ЕУ има надлежност предузимања мера у сврху подстицања, координирања и допуњавања мера држава чланица. Једна од тих мера се односи на стручни кадар у реализацији програма спорта (Табела 1).

Табела 1 Квантитативни показатељи односа између броја дипломираних тренера и понуде радних места y EY (Petry i sar, 2008)

\begin{tabular}{cccc}
\hline Ниво тренера & $\begin{array}{c}\text { Број дипломираних } \\
\text { (годишње) }\end{array}$ & $\begin{array}{c}\text { Број радних } \\
\text { места }\end{array}$ & $\begin{array}{c}\text { Годишња } \\
\text { потреба }\end{array}$ \\
\hline Ниво мастера и трогодишњих студија & $15.000+70.000=85.000$ & 120.000 & 30.000 \\
Ниво двогодишње школе и инструктора & $15.000+100.000=115.000$ & 410.000 & 100.000 \\
$\begin{array}{c}\text { спорта } \\
\text { Ниво аниматора спорта }\end{array}$ & 150.000 & 280.000 & 70.000 \\
\hline
\end{tabular}


У једној од низа директива Савета Европе уређује се материја надзора над здрављем и прописује се обавеза да радници (у ту категорију спадају и професионални спортисти) имају право на здравствени надзор који одговара здравственим и безбедносним ризицима њиховог посла.

Значајан документ ЕУ за област спорта представља и Акциони план ЕУ од 2000. до 2004. године, који је касније допуњаван и мењан новим. У Акциономплану се посебно указује на чињеницу огромног утицаја спортских активности на понашање читаве јавности појединог друштва као и на утицај који велике звезде спортских такмичења имају на понашање деце и омладине.

Од оснивања ЕУ, поједине невладине организације својим активностима и документима, омогућиле су повезивање и размену искустава, реализацију пројеката, прикупљање и анализу података са упутствима повезаним са спортским активностима. Једна од организација је Европска невладина спортска организација (ЕНГСО) која у свом документу "Водич за дечији и омладински спорт” издаје упутства за спортске активности деце и омладине.

На Конференцији министара и старијих службеника одговорних за спорт и физичко васпитање (МИНЕПС) донета су документа о значају физичког васпитања и спорта, као и потреби заштите младих спортиста из перспективе и принципа који су утврђени Конвенцијом Уједињених нација о правима детета. Закључци МИНЕПС-а обавезују земље учеснице чија је Србија чланица.

Конференција "Спорт за развој” одржана у Београду марта 2008. године, у организацији Министарства омладине и спорта и Британског савета УНИЦЕФ-а, била је посвећена размени искустава у простору спорта најмлађих. Резултат ове међународне конференције посвећене, пре свега, борби против насиља и расизма у спорту, је пројекат и акција "Карактером против насиља" који је потписало 70 националних спортских савеза у форми етичких кодекса: Повеља младих спортиста, Кодекс понашања спортиста, Етички кодекс тренера и наставника физичког васпитања, Кодекс понашања родитеља у спорту, Кодекс понашања спортских функционера, Етички кодекс спортских судија и посебно Етички кодекс спортских судија у омладинском спорту, Кодекс понашања гледалаца, Кодекс спортских новинара Србије - додатак Кодексу новинара Србије (Бачанац и сар. 2011, стр. 201-211)

\section{ДЕЧИЈИ СПОРТ У НАЦИОНАЛНОМ СИСТЕМУ СПОРТА}

Од 2001. године у Србији се уочавају активности којима се настоји да се препознају сви актери и чиниоци система спорта, и да се њихово пословање усаврши у корист непосредних корисника, спортисте и самог спорта. Дефинисано је да се у делокругу система спорта Републике Србије, поред система спорта у ужем смислу, налазе и физичко васпитање и школски спорт, спорт за све, науке спорта, ангажованост и улога волонтера, запослени у спортским организацијама, научници, али и разна удружења и институције, легислатива, тренажни центри, спортско наслеђе... (Схема 1.)

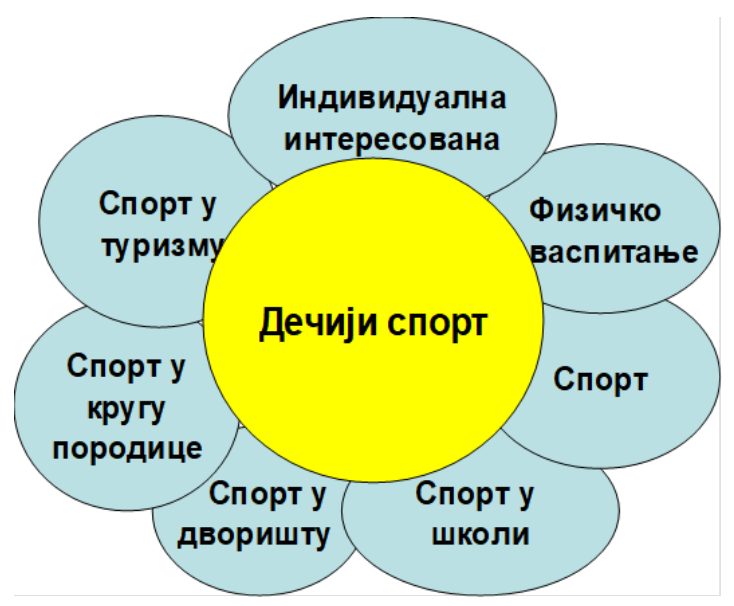

Схема 1 Окружење у којем се одвија дечије „спортско“ одрастање (Јевтић и сар. 2011 стр 20.)

Теоријска разматрања Дечијег спорта наглашавају нужност организовања спорта, полазећи од потреба и права детета и подстицања јединства моторичког, социјалног и интелектуалног развоја, узимајући у обзир позитивне и негативне ефекте спорта на дете (Табела 2). 
Табела 2 Позитивни и негативни ефекти спорта на дете (Merkel, 2013)

\begin{tabular}{|c|c|}
\hline Позитивни ефекти спорта & Негативни ефекти спорта \\
\hline \multicolumn{2}{|c|}{ Физички утицаји } \\
\hline $\begin{array}{l}\text { • увећана физичка активност } \\
\text { • подршка физичком и здравственом фитнесу } \\
\text { • дугогодишњи физички, емотивни, и здравствени } \\
\text { бенефити } \\
\text { • смањење ризика од гојазности и пратећих обољења } \\
\text { • минимизирање у развоју хроничних обољења } \\
\text { • подршка здрављу } \\
\text { • моторичке вештине }\end{array}$ & $\begin{array}{l}\text { • повреде } \\
\text { • не-компетентни тренери } \\
\text { • недовољна брига о сигурности } \\
\text { • недостатак хуманистичких наука у спорту } \\
\text { • злостављање }\end{array}$ \\
\hline \multicolumn{2}{|c|}{ Психички утицаји } \\
\hline $\begin{array}{l}\text { - смањење депресије } \\
\text { • смањење размишљања о суициду } \\
\text { • подршка позитивном понашању } \\
\text { • развој вештина } \\
\text { • подршка самовредновању, оптимизму ... }\end{array}$ & $\begin{array}{l}\text { • увећање стреса и врхунско постигнуће } \\
\text { - ефекти испадања из спорта } \\
\text { • нагласак на такмичарској активности } \\
\text { • нереална очекивања по питању академског } \\
\text { постигнућа и каријере након спорта } \\
\text { - злостављање }\end{array}$ \\
\hline \multicolumn{2}{|c|}{ Социјални утицаји } \\
\hline $\begin{array}{l}\text { • подршка социјалним вештинама } \\
\text { • животно учење } \\
\text { • подршка друштвено прихватљивом понашању } \\
\text { • подршка друштвено одговорном понашању } \\
\text { • управљање и лидерске вештине } \\
\text { • академско постигнуће } \\
\text { • посвећеност и постављање циљева } \\
\text { - подршка карактеру }\end{array}$ & $\begin{array}{l}\text { • недовољна брига о безбедности и } \\
\text { сигурности, опреми, просторима за тренинг } \\
\text { и такмичења } \\
\text { • цена коштања } \\
\text { • неравноправност у групи (економска, } \\
\text { етичка, расна, полна) } \\
\text { • злостављање }\end{array}$ \\
\hline
\end{tabular}

У циљу афирмације позитивних и минимизирање негативних ефеката спорта на дете, рационална и сврсисходна мера је планирање, које се спроводи од појединачног часа до вишегодишњег плана развоја, сходно чему је, за остварење јединства моторичког, социјалног, интелектуалног развоја детета кроз спорт потребно дефинисати циљеве за сваки ниво учешћа детета у спорту (Табела 3 ).

Табела 3 Циљеви дечијег спорта (модификовано према: Јевтић, 2018)

\begin{tabular}{|c|c|c|}
\hline \multicolumn{2}{|c|}{ ЦИЉЕВИ ДЕЧИЈЕГ СПОРТА } & \multirow{2}{*}{$\begin{array}{c}\text { Изузетност као } \\
\text { Циљ дечијег спорта } \\
\text { Напредовање према } \\
\text { „Изузетности у дечијем } \\
\text { спорту“ }\end{array}$} \\
\hline $\begin{array}{c}\text { Циљеви у такмичарском } \\
\text { спорту }\end{array}$ & $\begin{array}{c}\text { Омогућити надареној и } \\
\text { заинтересованој деци да } \\
\text { напредују према овом циљу }\end{array}$ & \\
\hline $\begin{array}{c}\text { Васпитно-образовни } \\
\text { цилеви }\end{array}$ & $\begin{array}{c}\text { Подршка васпитно-образовним } \\
\text { циљевима спорта и бенефита } \\
\text { ьиховог развоја }\end{array}$ & $\begin{array}{c}\text { Напредовање према } \\
\text { „Нзузетности учешћа у } \\
\text { дечијем спорту“ }\end{array}$ \\
\hline $\begin{array}{c}\text { Социјално-здравствени } \\
\text { циљеви }\end{array}$ & $\begin{array}{c}\text { Подршка социјалним циљевима } \\
\text { и јавном здрављу, тежити } \\
\text { инклузији свих социјалних } \\
\text { група, нарочито оних са високим } \\
\text { степеном ризика по социјално } \\
\text { прихватљиво-одговорно } \\
\text { понашање }\end{array}$ & $\begin{array}{c}\text { Напредовање према } \\
\text { „Личном и социјалном } \\
\text { благостању и спорту као } \\
\text { животном стилу“ }\end{array}$ \\
\hline
\end{tabular}


Трагање за бољом организацијом појединих чинилаца структуре система спорта Србије, непосредно по ступању државне независности Републике Србије, ималојезарезултат сачињавање „Идејног оквира система спорта Србије” (Јевтић, документ ОКС, 2006). На заједничкој седници Председништва Олимпијског комитета Србије, и представника спортских организација и државних органа, усаглашен је Идејни оквир за систем спорта у Србији. У том документу, као приоритети даљег развоја су издвојени дечији и омладински спорт. Исти су са позиције спорта у ужем смислу, препознати као „врата за улазак у елитни спорт“ (освајање медаља на ОИ, СП, ЕП) и очување конкурентности резултата које постижу појединци и тимови Србије (Јевтић и cap., 2010 стр. 89). Ипак, као и сваки други идејни документ, Идејни оквир није имао капацитет, али ни мандат да у целости уреди систем спорта, тако да су одређена питања, остала да се разраде кроз националну стратегију и да се преточе у законска решења и подзаконска документа!

\section{ДЕЧИЈИ СПОРТ У НАЦИОНАЛНИМ ДОКУМЕНТИМА}

Иницијативе Олимпијског комитета Србије (ОКС) из 2006. године, истакнуте у Идејном оквиру, текле су и у правцу стварања нових докумената, пре свега интегрисања спорта у текст Устава Републике Србије, Правилника о националним признањима, наградама за развој спорта, као и оснивању Министарства омладине и спорта. Све иницијативе ОКС-а су прихваћене од државних органа, чиме је учињен искорак у креирању окружења за даљи развој система спорта Србије и његовог ближег и даљег окружења. Усвајањем Националне стратегије спорта за период 2009-2013, а потом и за период 2014-2018. године настављено је са процесом уређења стратегије развоја самог спорта и његовог окружења, при чему важно место има одлука о формирању Министарства омладине и спорта (МOC).

\section{Устав Републике Србије}

Устав Републике Србије из 2006. године први пут уврштава спорт, као уставну категорију, и прописује да Република Србија уређује и обезбеђује систем у области спорта (чл. 97) чиме је спорт дефинисан као активност од друштвеног интереса. Устав је прописао одговорности Републике, покрајина и локалне управе у афирмацији вредности спорта. С тим у вези, развој спорта је одређен већим бројем друштвених фактора које је могуће груписати у две групе: (а) факторе који спорт виде као део стратегије развоја друштва и (б) факторе који су детерминисани политичком вољом парламентарне већине. Уставом је предвиђено да се општине, преко својих органа, старају о задовољавању потреба грађана у области спорта и физичке културе (чл. 109).

\section{Закон о спорту}

Када је реч о физичкој активности и спорту, у Републици Србији закони регулишу два велика система - систем образовања и васпитања и систем спорта.

Закону о спорту из 2009. године, претходио је Закон о физичкој култури из 1981. године, након чега су уследили закони о спорту усвојени 1996, следе измене и допуне из 2012. а потом усвајање Закона из 2016. године. Сваки од усвојених закона садржавао је мисију унапређења статуса и организацију спорта, а новине које доноси последњи Закон из 2016. године, за разлику од претходног, су:

- здравствени прегледи за децу од 6 до 16 година су бесплатни;

- обавезно осигурање спортиста за време наступа за репрезентацију;

- боља заштита деце у сфери посредовања менаџера, дужини и транспарентности уговора.

Најзначајни чланови овог Закона о спорту који се односе на дечији спорт су:

- дефиниција дечијег спорта: „Спорт деце јесте организован облик физичког вежбања, односно спортских активности, усклађен са антрополошким карактеристикама дечјег узраста“; 
- дефиниција узраста дете: „Под децом у смислу става 4. овог члана сматрају се лица која имају мање од 16 година живота“;

- прописивање минималне професионалне компетентности стручњака за рад са децом „Спортски стручњаци су лица која имају одговарајуће више или високо образовање у области спорта, односно физичке културе или су оспособљена, у складу са чланом 26. став 2. и чланом 29. ст. 1-4. овог закона, за обављање одређених стручних послова у спорту, ако законом није друкчије одређено“;

$\checkmark$ Стручно-васпитни рад са децом могу обављати само спортски стручњаци који имају одговарајуће више или високо образовање у области физичког васпитања и спорта или су, поред основне стручне оспособљености, и посебно стручно оспособљени за стручни рад са децом ...”;

- предодређење функције институција система спорта и владиних институција у спровођењу мисије дечијег спорта, и то:

$\checkmark$ „Надлежни национални спортски савез издаје лицима која сустекла одговарајуће стручно звање у области спорта, дозволу за рад“;

$\checkmark$ „Спортски савез Србије обавља послове којима се обезбеђују услови за праћење, развој и унапређење спортске рекреације, спорта деце, укључујући физичко васпитање деце предшколског узраста и школски спорт...";

$\diamond$ Почев од 1992. године спортска такмичењаученикаорганизујусекаојединствен систем за цело подручје Републике Србије, а од 1997. такмичењима руководи Савез за школски спорт и олимпијско васпитање. (Основан 1969, члан је Међународне федерације школског спорта - ИСФ од 2005. године);

- „Републички завод јесте установа која обавља делатност ради развоја стручног рада и задовољавања стручних потреба у области спорта. Делатност Републичког завода обухвата: 1) периодична тестирања, односно праћење антрополошких способности и карактеристика деце, омладине и одраслих; 15) унапређење развоја спорта деце и младих“;

- „Трошкови програма којима се остварује општи интерес у области спорта из члана 116. став 1. овог закона морају се односити, по правилу, најмање $15 \%$ на активности повезане са спортом деце“;

- „Потребе и интереси грађана за чије се остваривање обезбеђују средства у буџету јединица локалне самоуправе, у складу са законом, јесу: 1) подстицање и стварање услова за унапређење спортске рекреације, односно бављења грађана спортом, посебно деце, омладине, жена и особа са инвалидитетом; 6) физичко васпитање деце предшколског узраста и школски спорт (унапређење физичког вежбања, рад школских спортских секција и друштава, општинска, градска и међуопштинска школска спортска такмичења и др.); 14) унапређивање стручног рада учесника у систему спорта са територије јединице локалне самоуправе и подстицање запошљавања висококвалификованих спортских стручњака и врхунских спортиста“;

- „Утврђивање здравствене способности ученика узраста од шест до 14 година живота из става 9. овог члана врши изабрани лекар педијатар надлежне здравствене установе током обавезног систематског прегледа у складу са законом, односно лекар специјалиста спортске медицине или педијатрије надлежне здравствене установе када се утврђивање здравствене способности врши изван систематског прегледа. Трошкови утврђивања здравствене способности ученика из става 9 . овог члана обухваћени су обавезним здравственим осигурањем...“;

Закон прецизно регулише ко врши надзор (поглавље 10) и које су санкције за његово неспровођење (поглавље 11). 


\section{Стратегија развоја спорта у Републици Србији за период 2009-2013}

У овом документу Владе Републике Србије, између осталог, за националне стратешке циљеве развоја спорта су одређени:

- развој и унапређење физичког вежбања деце у предшколским установама;

- јачање школског и универзитетског спорта и успостављање функционалног система школских и универзитетских спортских такмичења.

Полазиште за креирање ових исхода Стратегије налази се у анализама које су обавиле владине и спортске организације које су, између осталог, уочиле и закључиле следеће:

- спорт деце и омладине је у веома тешком стању;

- смањен је број реализованих недељних часова физичког васпитања;

- недовољан је број фискултурних сала које су опремљене по утврђеним нормативима, што утиче на примере ерозије у квалитету и стандардима наставе;

- смањенајесигурност и безбедност ученика, уз питања о проблемима ангажовања наставника;

- проблем паралелизма у спортским такмичењима и стремљењу ка елитизму појединих школа које се у процесу школских такмичења више ослањају на ученике спортисте који активно тренирају у спортским клубовима;

- пораст приватне иницијативе у рекреативном вежбању (у просторима од вртића, школа, М3, до подрума и склоништа);

- недостатакевиденције о броју рекреативних програма, објеката за рекреацију, као и о степену образованости кадра који се бави инструктажом;
- недостатак норматива о минималним условима што се тиче опреме, реквизита и простора за рекреативно вежбање у објектима;

- непостојање програмских основа за повећање броја деце укључених у спорт;

- изостанак стратегије развоја спорта у кругу становања (спорт у дворишту) која би дефинисала спорт на нивоу школе, група школа и локалне самоуправе. Без решења наведених просторних, програмских, кадровских и погодности у коришћењу објеката нема реализације акционог плана.

\section{Акциони план Стратегије развоја спорта 2009-2013}

За спровођење Стратегије развоја спорта у Републици Србији, дефинисан је Акциони план у коме су за циљеве постављени (Табела 4):

- успостављање савременог система спорта у предшколским, школским и високошколским установама;

- промовисање спорта деце и омладине;

- подизање капацитета струковних удружења из области спорта деце и младих.

Акциони план је предвидео следеће активности:

- формирање радне групе за анализу стања;

- анализа стања у предшколским, школским и универзитетским установама;

- припрему препорука за унапређење спорта у наведеним установама;

- расписивање конкурса за финансирање спорта у наведеним установама;

- унапређење струковних удружења. 
Ропрет Р., Дечији спорт у националним документима..., ФИЗИЧКА КУЛТУРА 2019; 73 (1): 134-150

Табела 4 Акциони план Министарства омладине и спорта у области спорта деце и омладине

\begin{tabular}{|c|c|c|c|}
\hline ЦИљ & АКТИВНОСТИ & ИНДИКАТОР & Рок \\
\hline \multirow{7}{*}{ 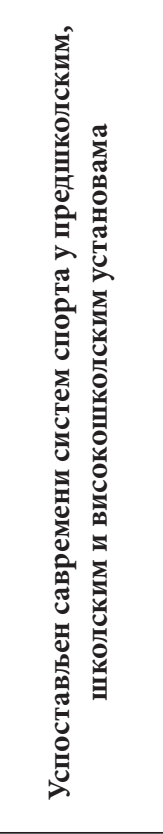 } & $\begin{array}{l}\text { Формирање радне групе која ће се бавити } \\
\text { модернизацијом система спорта у предшколским, } \\
\text { школским и високошколским установама }\end{array}$ & $\begin{array}{l}\text { - Формирана радна група која ће } \\
\text { се бавити модернизацијом система } \\
\text { спорта у предшколским, школским и } \\
\text { високошколским установама }\end{array}$ & 2009 \\
\hline & $\begin{array}{l}\text { Анализа стања у предшколском, школском и } \\
\text { универзитетском спорту }\end{array}$ & $\begin{array}{l}\text { - Урађена и објављена анализа } \\
\text { стања у предшколском, школском и } \\
\text { универзитетском спорту }\end{array}$ & 2010 \\
\hline & $\begin{array}{l}\text { Анализа спортске опреме и реквизита, спортских } \\
\text { терена и сала у предшколским, школским и } \\
\text { високошколским установама }\end{array}$ & $\begin{array}{l}\text { - Установљене потребе предшколских } \\
\text { установа, школа и универзитета за } \\
\text { спортском опремом и реквизитима и } \\
\text { просторним капацитетима }\end{array}$ & 2011 \\
\hline & $\begin{array}{l}\text { Припрема препорука за успостављање } \\
\text { јединственог система такмичења у школском } \\
\text { спорту на свим нивоима }\end{array}$ & $\begin{array}{l}\text { - Издате препоруке за успостављање } \\
\text { јединственог система такмичења у } \\
\text { школском спорту на свим нивоима }\end{array}$ & 2011 \\
\hline & $\begin{array}{l}\text { Припрема препорука за унапређење наставе } \\
\text { физичког васпитања у школама }\end{array}$ & $\begin{array}{l}\text { - Издате препоруке за унапређење } \\
\text { наставе физичког васпитања у школама }\end{array}$ & 2011 \\
\hline & $\begin{array}{l}\text { Припрема препорука за унапређење спорта у } \\
\text { предшколским установама }\end{array}$ & $\begin{array}{l}\text { - Издате препоруке за унапређење спорта } \\
\text { у предшколским установама }\end{array}$ & 2012 \\
\hline & $\begin{array}{l}\text { Припрема препорука за унапређење спорта на } \\
\text { универзитетима }\end{array}$ & $\begin{array}{l}\text { - Издате препоруке за унапређење спорта } \\
\text { на универзитетима }\end{array}$ & 2012 \\
\hline \multirow{2}{*}{ 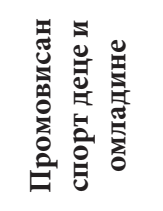 } & $\begin{array}{l}\text { Расписивање конкурса за финансирање кампања } \\
\text { промоције спорта у предшколским, школским и } \\
\text { високошколским установама, на годишњем нивоу }\end{array}$ & - Број финансираних кампања & 2010 \\
\hline & $\begin{array}{l}\text { Покретање интернет сајта са темама спорта и } \\
\text { рекреације деце и омладине }\end{array}$ & $\begin{array}{l}\text { - Покренут сајт са темама спорта и } \\
\text { рекреације деце и омладине }\end{array}$ & 2010 \\
\hline 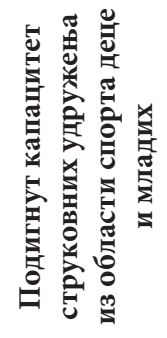 & $\begin{array}{l}\text { Припрема препорука за унапређење рада } \\
\text { струковних удружења из области спорта деце и } \\
\text { младих - УПФК }\end{array}$ & $\begin{array}{l}\text { - Састављене препоруке за унапређење } \\
\text { рада струковних удружења из области } \\
\text { спорта деце и младих - УПФК }\end{array}$ & 2010 \\
\hline
\end{tabular}

Анализа података пре 2009. и након 2013. године показује да:

- доношење и реализација Стратегије развоја спорта у Републици Србији за период од 2009. до 2013. године, са пратећим акционим планом, значајно је унапредило затечено стање и поставило чврсте темеље за уређење система спорта у Републици;

- мере које су предузете на спровођењу стратегије дале су значајне резултате у већини стратешких области, а посебно у делу који се односи на приоритете које је дефинисала Стратегија развоја спорта: спорт деце и омладине, спортске објекте и врхунски спорт;

- потребан је рад на унапређењу реализације наставе физичког васпитања и на пољу квалитета, али и на пољу повећања броја часова физичког васпитања;

- повећан је број оних који кажу да се баве спортом у било којој мери са $37 \%$ на $44 \%$. (једном недељно - 3\% повећање, два и више пута - 15\% повећање).

\section{Стратегија развоја спорта у Републици Србији за период 2014-2018}

У Стратегији је наглашен значај развоја физичког вежбања јер према демографским подацима број радно способног становништва у Србији опада, скоро сваки пети одрасли становник 
је гојазан, сваки трећи конзумира цигарете, око $40 \%$ свакодневно или повремено конзумира алкохол, а скоро половина становништва има хипертензију. Спортом се бави, једном недељно $10 \%$, а половина популације се уопште не бави физичким вежбањем. Финансијски ресурси су ограничени, инфраструктура неадекватна и недостајућа, недостатак јасних критеријума финансирања, непоштовање Закона, несразмера финансирања рекреативног и такмичарског спорта.

Стратегијом су дефинисане четири приоритетне области, а акционим планом су дефинисани како општи тако и посебни циљеви. Стратегија своје деловање посебно усмерава на следеће приоритете:

- развој спорта деце и омладине, укључујући и школски спорт;

- повећање обухвата бављења грађана спортом кроз развој и унапређење спортске рекреације;

- развој и унапређење врхунског спорта;

- развој и унапређење спортске инфраструктуре.

У односу на претходну, Стратегија за период 2014-2018, у сегменту унапређења школског и универзитетског спорта, значајно је употпуњена конкретнијим подацима, исходима и ближе дефинисаним посебним циљевима:

- мисија - осигурати темеље система спорта:у делукоји сеодноси наспортуинституцијама, спорт у школама и све видове укључења деце у спортске активности;

- очекивани исходи - да до 2018, путем реализације ове стратегије, очекивани исходи буду:

$\checkmark$ веће учешће деце и омладине школског узраста у физичком вежбању и организованим спортским активностима унутар школског спорта; односно повећан број деце и омладине која се организовано баве спортским активностима за $15-20 \%$;

$\checkmark$ веће учешће деце и омладине у систему спорта преко спортских организација и савеза; односно, повећан број деце и младих који се баве школским и универзитетским спортом за 10-15\%.
У оквиру Стратегије истакнуто је да:

- сви млади треба да добију адекватно физичко образовање и стекну основне спортске вештине у оквиру редовног наставног програма или у оквиру ваннаставних активности, чиме се омогућава свакодневно бављење спортом;

- посебно девојчицама треба обезбедити више могућности да се баве спортом и остану у спорту, с тим да ниво и интензитет тренинга и такмичења треба да буде адекватан њиховом узрасту и физичком и менталном стању. Због тога треба посебно подржати оне спортове у којима се девојчице у значајној мери баве спортом.

\section{Акциони план Стратегије развоја спорта 2014-2018}

За спровођене Стратегије дефинисан је Акциони план. У оквиру општег циља развоја спорта деце и омладине, Акциони план је дефинисао посебне циљеве:

- побољшање материјално-техничких услова за реализацију активности школског и универзитетског спорта;

- повећан број спортских секција и других ваннаставних спортских активности у оквиру школског и универзитетског спорта;

- повећано учешће ученика и студената на школским и универзитетским спортским приредбама (спортским манифестацијама и спортским такмичењима);

- побољшан стручно педагошки рад и унапређена институционална сарадња у оквиру школског и универзитетског спорта;

- подстакнуто значајније укључивање јединица локалне самоуправе у реализацију и унапређење школског и универзитетског спорта;

- унапређење медијског праћења и промоција школског и универзитетског спорта с циљем неговања културе спортског понашања, фер плеја, сарадње, толеранције и поштовања различитости на спортским теренима и поред њих;

- унапређене везе између школа и организација у области спорта и подстакнути програми у спортовима који привлаче децу и омладину. 


\section{Документа Националног просветног савета}

На својој 78. седници, одржаној 29. маја 2012. године у Београду, Национални просветни савет је донео одлуку да предложи мере за побољшање здравља деце и омладине, унапређивањем наставе физичког васпитања кроз формирање радне групе и израде документа под називом „Предлог мера за побољшање наставе физичког васпитања“. У документу су дефинисане следеће мере:

- потребно је успостављање Система праћења физичког развоја и развоја моторичких способности ученика у оквиру Образовног система на територији читаве Србије (успостављање базе података, анализа стања и предузимање мера за унапређење здравља ученика - у току је пројекат који су заједно започели Завод за вредновање квалитета образовања и васпитања и Факултет спорта и физичког васпитања у Београду);

- предузети мере за уједначавање просторно техничких услова за реализацију наставе физичког васпитања на територији читаве Србије у складу са донетим Стандардима за реализацију наставе и Стандардима постигнућа ученика;

- настава физичког васпитања је због своје сложености у великој мери ограничена у примени доследно спроведене индивидуализације. Из тог разлога се предлаже реализација наставе у диференцираном облику којом би се добио виши ниво постигнућа ученика. Потребно је и у физичком васпитању ревитализовати допунску и додатну наставу. Допунском наставом били би обухваћени ученици са мањим нивоом моторичких способности и ученици којима је потребно посебно физичко вежбање (корективна гимнастика). Додатном наставом били би обухваћени ученици посебно талентовани за спорт и друге моторичке активности. Као и у другим предметима, тако је и у физичком васпитању потребно је стварање услова за рад са талентованом децом, већ у млађем узрасту. Основни услов је како препознати талентовану децу и како организовати рад са њима. У млађем школском узрасту идентификација талентоване деце и рад са њима је изостао;

- све активности у вези са физичким, односно спортским активностима ученика (школски спорт) су моћно средство у обезбеђивању превентивне улоге у заштити деце/ ученика од аберантног понашања и насиља;

- сва спортска школска такмичења увести у Систем Министарства просвете и у школски календар за текућу годину (као што је случај са такмичењима у оквиру других предмета);

- препоручује се да наставу физичког васпитања у млађим разредима (3. и 4.) реализују наставници физичког васпитања у свим школама у којима је то могуће (неопходно је да у Закону о основама система образовања и васпитања то буде предвиђено), а у школама у којима за то не постоје услови наставници разредне наставе уз стручно-инструктивни рад наставника физичког васпитања (ова препорука проистиче из већег броја истраживања која су се бавила проблематиком постигнућа у настави физичког васпитања у млађим разредима);

- омогућити исте услове за спровођење наставе физичког васпитања са млађим и старијим разредима (уколико има услова омогућити одржавање наставе физичког васпитања млађих разреда у школској сали);

- предлог да се поново уведе педагошки надзор;

- због израженог недостатка редовне физичке активности деце и ученика, треба да се размотри и оперативно разради већи број пројеката који подстичу самоорганизовање и организовано вежбање ученика, као што су: спортски викенди у школском дворишту, летњи и зимски распуст у школском дворишту, модел СПРЕТ-а ученика, спортско-рекреативни кампови ученика и сл...

- ванчасовне активности и школска такмичења могу се унапредити ангажовањем наставника физичког васпитања који би се искључиво бавио организацијом спортских 
и рекреативних активности ученика у њихово слободно време (у току радних дана и током викенда), као и организовањем програма спортских и рекреативних активности ученика у школском простору, током зимског и летњег распуста;

- омогућити отварање и коришћење школских сала, током зимског и летњег распуста, за планирану допунску и додатну наставу и слободно изабране спортске активности ученика;

- у средњој школи иновирати програм физичког васпитања у циљу омогућавања решавања задатака физичког васпитања у складу са објективним условима за извођење наставе. Наставницима би на тај начин било омогућено да у већој мери сами бирају садржаје физичког вежбања у складу са потребама и могућностима ученика;

- заједно са Министарством омладине и спорта и Министарством здравља пронаћи решење за буџетско финансирање изборне наставе физичког васпитања студената на државним универзитетима.

\section{Правилници Министарства омладине и спорта}

Поред Закона о спорту, Стратегије развоја спорта и Акционог плана, Минстарство омадине и спорта је донело 22 подзаконска акта/правилника, за област дечијег спорта од непосредне важности су:

- Правилник о утврђивању здравствене способности спортиста за обављање спортских активности и учествовање на спортским такмичењима («Службени гласник РС», број 15/12);

- Правилник о условима за обављање спортских делатности («Службени гласник РС», број 63/13);

- Правилник о спортским гранама од посебног значаја за Републику Србију («Службени гласник РС», бр. 72/11 и 25/13);

- Правилник о надзору над стручним радом у области спорта («Службени гласник РС», број 92/11);

- Правилник о дозволи за рад спортских стручњака («Службени гласник РС», број 7/13);
- Правилник о ближим условима за обављање спортских активности и спортских делатности («Службени гласник РС», број 17/13);

- Одлука о образовању Националног савета за борбу против насиља и недоличног понашања гледалаца на спортским приредбама («Службени гласник РС», бр. $65 / 11$ и 100/12).

Доношење новог Закона о спорту (2016) условило је да се до почетка 2018. године постојећи правилници ускладе са новим Законом.

\section{НАСТАВНИ ПРОГРАМИ АКРЕДИТОВАНИХ ВИСОКОШКОЛСКИХ УСТАНОВА}

Од 2001. године на Факултету спорта и физичког васпитања Универзитета у Београду, у акредитованом програму академских и струковних студија, установљен је предмет „Дечији спорт“. Са програмом предмета је усклађен уџбеник „Дечији спорт - од праксе до академске области“ (ур: Јевтић Б; Радојевић Ј., Јухас И, и Ропрет Р., 2010). Извод из Рецензије ближе описује стручни (пракса) и академски капацитет области дечијег спорта, и при томе рецензенти наводе (Јовановић, С; Радовановић, И):

„Книга “Дечији спорт од праксе до академске области”, поделена у два дела (Теорија дечијег спорта и Примери праксе дечијег спорта), садржи 18 поглавља као стручни и научни прилог 22 аутора са Факултета спорта и физичког васпитана и 3 аутора са других институичја Србије. Книга чини јединствену и кохерентну публикацију која покрива академску области која изучава дете и негов физички, психички, интелектуални, друштвени развоја кроз спорт. Она је резултат дугогодишьег рада аутора на проблемима и простору области “Дечији спорт”. Доволним бројем аутоиитата аутори су показали да су референтни и компетентни за суочаване са овом комплексним теоријскими практичним простором. Снага книге је јасно наглашено место u значај cnopma y одрастану детета и место 
спорта у прихватану универзалног вредносног оквира, као и вредности друштва и појединца. Као ретко које сазнајно подручје, дечији спорт је од идеје, преко предмета стигао до смисла и вредности којима данас припадају документа (национална стратегија и акииони план) али и оквир система наука који чине ово образовноваспитно подручје."

На Учитељском факултету у Београду, установљен је предмет Васпитање кроз спорт, у оквиру којег је публикована и истоимена књига „Васпитање кроз спорт“ (Бачанац и Радовановић, 2007).

\section{ДОКУМЕНТА О ПРАВИМА ДЕТЕТА И ХУМАНОМ ОДРАСТАњУ КРОЗ СПОРТ}

Крајем 1970-их Америчко национално удружење за спорт и физичко васпитање је донело Повељу права младих спортиста. Повеља садржи 10 елементарних права (једанаесто, о заштити од допинга, додала је др. сци. Бачанац љ., психолог Републичког Завода за спорт). Повеља може послужити као основни путоказ за усмеравање даљег развоја омладинског спорта. Она представља сажетак главних филозофских позиција и циљева дечијег и омладинског спорта.

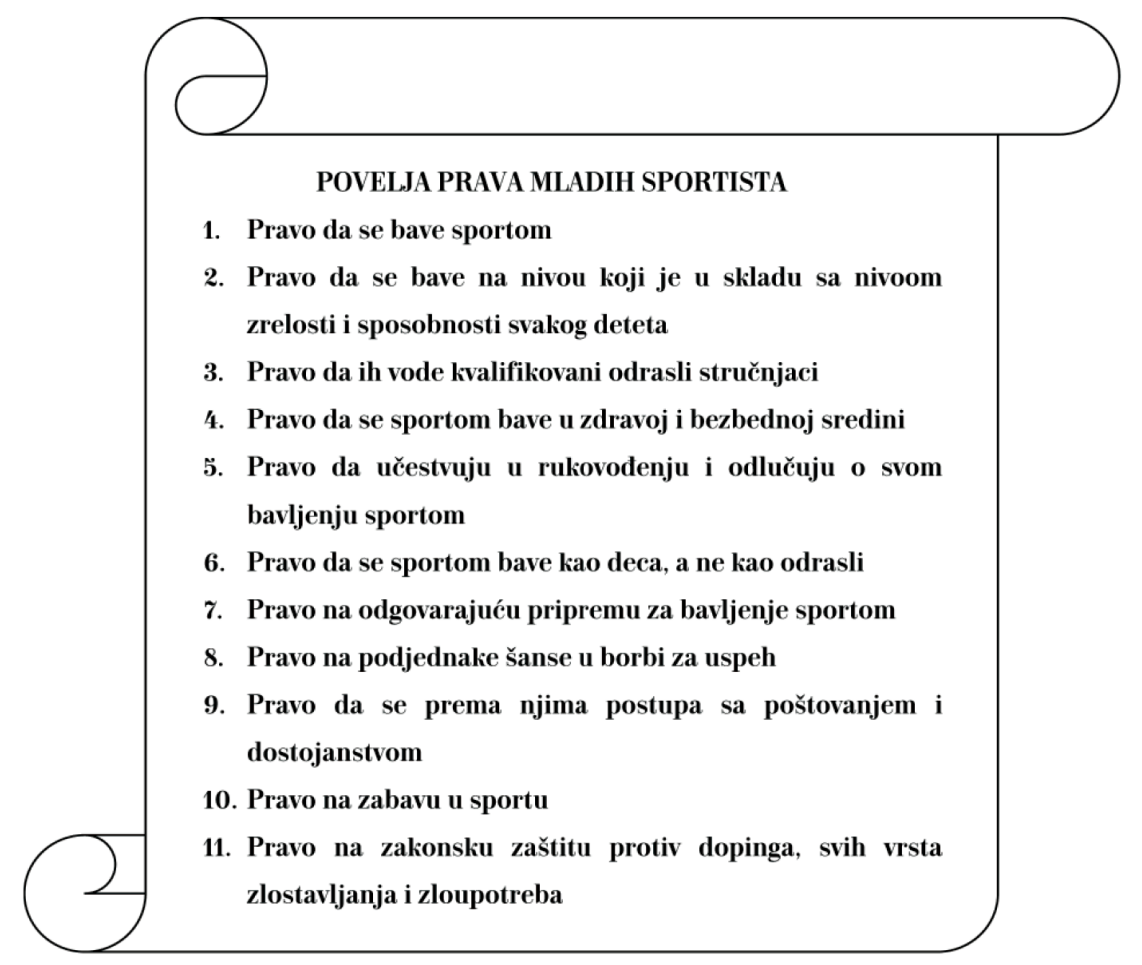

Слика 1 Повеља права младих спортиста (Бачанац и сар., 2011, стр. 201)

Осим у нормативним документима, о спорту деце се расправља са различитих становишта, из којих проистичу најмање три вредносне оријентације (Јевтић и сар, 2010, стр. 19):

- “спорт задецу” - становиште које наглашава да спорт треба да буде у служби детета;
- “деца за спорт” - усмеравања деце и омладине према спорту у коме егзистира модел ране идентификације талената и њихово укључивање у националне програме врхунског спортског постигнућа и

- „оптимално спортско постигнуће у интересу развоја детета“ - ово је гледиште 
које инсистира на поштовању законитости биолошког, социјалног и психо-моторног развоја детета. Усмерава га према спортској, односно физичкој активности чији је циљ обезбеђивање „хуманог света дечијег спорта“.

Без обзира на то о ком се гледишту, или организованом систему ради, у европским процесима се, као императив, наглашава потреба успостављања “хуманог света дечијег спорта" који, као темељ система, обезбеђује и хумани свет омладинског спорта.

Будућност дечијег спорта се може реализовати кроз препоруке из «аспекта» душтва, родитеља и тренера (Табела 5).

Табела 5 Препоруке за успех дечијег спорта (Merkel, 2013)

\begin{tabular}{|c|c|c|}
\hline Друштво & Родитељи & Тренери \\
\hline $\begin{array}{l}\text { - Тренинг тренера } \\
\text { - Безбедност и сигурност деце } \\
\text { - Финансирање и буџет } \\
\text { - Обука тренера у простору } \\
\text { безбедности } \\
\text { - Подршка политици и процедурама } \\
\text { - Подршка учешћу занемарених } \\
\text { група } \\
\text { - Већа расположивост простора, } \\
\text { опреме и реквизита } \\
\text { - Усмеравање принципима } \\
\text { - Обавезни педијатријски прегледи }\end{array}$ & $\begin{array}{l}\text { - Подршка родитеља и усмереност } \\
\text { ка бенефитима одрастања кроз } \\
\text { спорт и забаву, а не на победу } \\
\text { - Усмереност ка усвајању вештина } \\
\text { - Подршка током тренинга и } \\
\text { такмичења } \\
\text { - Промоција пожељног понашања, } \\
\text { срчаност, тачност, исхрана, } \\
\text { хидратација ... }\end{array}$ & $\begin{array}{l}\text { • Нагласак на игри и забави } \\
\text { • Без императива победе } \\
\text { • Подршка тиму и појединцу } \\
\text { • Већа усмереност ка физичкој } \\
\text { активности и учењу у односу на } \\
\text { финализацију вештина } \\
\text { • Компетентност за рад са децом } \\
\text { • Инструкције, методе и технике } \\
\text { рада одговарајуће детету } \\
\text { • Знања о спорту и правилима } \\
\text { • Знања о принципима тренинга, } \\
\text { моторичким способностима, } \\
\text { расту и развоју, исхрани, } \\
\text { динамици развоју вештина, } \\
\text { кондиције, резултата, } \\
\text { безбедности, повредама } \\
\text { • Анализа тренажне ситуације, } \\
\text { прпознавање фактора ризика, } \\
\text { мера заштите, прве помоћи }\end{array}$ \\
\hline
\end{tabular}

Један од начина за обезбеђење “хуманог света дечијег спорта” је изградња теорије, на коју би се наслањала пракса квалитетне физичке и спортске активности деце и омладине. Другим речима, стручњаци и научни радници морали би уложити напор како би се, унутар теорије спорта и спортског тренинга, као и теорија свих спортских грана, идентификовали и посебно обрадили проблеми дечијег и омладинског спорта. Таквим теоријским приступом, из кога би уследила и пракса, избегла би се ситуација у којој се, у простор рада са децом и младима, преносе обрасци рада са одраслима и тиме наноси штета, пре свега детету и младој особи, а затим и развоју спорта. Чињеница је да је омладински спорт основа сениорског спорта и зато га треба другачије организовати, прилагодити природи, потребама и могућностима деце, а не као до сада, по стандардима и моделима спорта одраслих.

За потребе Европске комисије, 2008. године je урађено истраживање (анализа) стања у дечијем спорту у 27 земаља чланица ЕУ (European Commission, 2008). Истраживање описује сву сложеност простора теорије дечијег спорта, чиме су идентификовани основни елементи, упутства и правац побољшања дечијег спорта путем активности и програма:

- наглашена је сложеност система тренинга деце и омладине (организација, финансирање, управљање, специјализовани тренажни центри, однос аматерских и професионалних спортова, место и улога клуба...);

- предложено је постојање квалитативних критеријума за акредитацију клуба, 
спортског центра, нова организациона структура клубова прилагођена потребама спорта деце и омладине. Квалитативни критеријуми су груписани у две групе, и то: критеријуми повезани са системом тренинга деце и омладине (број спортиста на тренингу и унутар групе, опрема и реквизити, простор за тренинг, обим тренинга и др.), и критеријума који су повезани са интегралним развојем младих спортиста (образовање, заштита младих спортиста, компетенција ангажованих појединаца...);

- постојање правних норми и документа, као и планови чланица ЕУ за допуну и измену постојеће регулативе у области дечијег и спорта младих;

- друштвени значај, као и финансирање програма и спортских центара, али и израда и примена квалитативних критеријума;

- образовање спортиста, и унутар њега трајање школовања, специјализоване школе и одељења, веза спорта и професионалне каријере, стипендије, етичке норме, програми по окончању спортске каријере;

- здравствена брига и заштита, медицинско праћење, опоравак, здравствене и навике у исхрани, повреде и обољења;

- заштита малолетника;

- превенција у допингу;

- права из уговорног односа, односи спортисте и клуба-савеза, слобода кретања спортисте, компензација за први тренажни клуб, социјално и пензијско осигурање, место становања спортисте;

- тренинг, трајање и учесталост тренинга у односу на узраст (од 6-8 год=240 сати/ год.; од 9-11 год=240-400 сати/год; од 12-15 год=до 800 сати/год; од 15-18 год до 1100 сати/год);

- технологија заједничких тренинга дечака и девојчица;

- професија и перманентно усавршавање тренера;

- приручници за тренере са поглављима тренинга деце и омладине;

- тренинг особа са посебним потребама, регулативни механизми, промоција, инклузија и

- спортске школе.

\section{Кодекси}

Поред закона и подзаконских аката, за област дечијег спорта су значајни: Етички кодекс, Повеља права младих спортиста, Кодекс понашања спортиста, Етички кодекс тренера и наставника физичког васпитања, Кодекс понашања родитеља у спорту, Кодекс понашања спортских функционера, Етички кодекс спортских судија, Етички кодекс спортских судија у омладинском спорту, Кодекс понашања гледалаца, Кодекс спортских новинара Србије додатак Кодексу новинара Србије

\section{Акције и кампање}

Различите невладине организације спороводе акције и кампање са циљем унапређења вредности дечијег спорта:

- Спортом против насиља, дроге, пушења;

- Карактером против насиља;

- Спорт ушколе.

\section{ТРЕНЕРИ ЗА РАД У ДЕЧИЈЕМ СПОРТУ}

Европски стандарди занимања „спортски тренер“ дефинишу се улогом спортског тренера и његовим компетенцијама (Јевтић и сар. 2010, стр 25). Са тим у вези, рад тренера може бити усмерен према:

- што већем броју учесника у спорту (учеснички спорт), или

- према изградњи спортског резултата (такмичарски спорт у пуном смислу).

Тренер, који је оријентисан према већем броју полазника ради са почетницима програме који нису моторички комплексни и који су прихватљиви свима (деца, адолесценти, одрасли). Тренерусмеренпремарезултатурадисанадареним спортистима, гради претпоставке за врхунски спортски резултат (деца, адолесценти, одрасли). Да би неки од програма за школовање тренера (на универзитету и/или кроз систем спорта; формални и неформални) имао карактеристике европског модела, он мора, као исход, да оспособи компетентног тренера. Компетентност гарантује обученост за постизање високог квалитета рада обе групе тренера (Радојевић и Јевтић, 2002).

Сваки нови ниво компетентности обезбеђује се даљим усавршавањем тренера, чиме се подстиче 
стручна и научна знатижеља, повезују и примењују усвојена знања, анализира и усавршава пракса и, чињенице користе на оптималан, сврсисходан и научан начин. Ово су велики захтеви, с обзиром на то да се већина чињеница о човеку и његовом „спортском бићу“ сазнаје научним путем и анализом најбоље праксе, те да се усавршавање одвија током вишегодишњег учења и рада.

Како би се изградио компетентан тренер, европска стручна удружења и удружења послодаваца, сачинили су конвенцију која одређује европски модел квалитета тренера, и која садржи следеће захтеве (Petru, Froberg, Madela, \& Tokarski, 2008):

- тренер игра главну улогу у стицању спортског искуства спортиста свих узраста и нивоа;

- да би испунио своју улогу, тренер мора да има одговарајућу компетентност и стално усавршавање (тренинг). При томе, компетентност мора бити успостављена у односу на групу -појединца са којима ради;

- тренери воде бригу о добром стању спортиста током развоја њихових способности;

- тренери морају да поштују права, дигнитет, вредност сваког спортисте, и да се према свима, без обзира на пол, етничко порекло, религију или политичку опредељеност, понашају једнако;

- тренери раде на отворен и кооперативан начин са свим субјектима и одговорни су за лично добро и добро резултата сваког спортисте;

- тренери спроводе тренинг високог стандарда заснованог на научним чињеницама и актуелном искуству технологије тренинга;

- $\quad$ научни принципи треба да буду примењени на сваком од нивоа рада тренера;

- одговорност и професионална компетентност тренера се гради од почетног до највишег нивоа;

- сви тренери морају имати квалификацију која је верификована од стране надлежне спортске федерације и компетентног националног тела, одређеног законом;

- оквир за препознавање тренерске компетентности и квалификације даје Удружење тренера Европе;
- механизме претходног образовања и текуће компетентности треба што пре дефинисати и дати критеријуме за њихово признавање и

- успостављање система лиценцирања тренера који ће бити међународно препознат и валидан.

\section{ЗАКЉУЧАК}

Спорт, анарочитодечијиспорт семоранеговати као моћно средство подршке у одрастању, развоју животних вештина и навика. Он је део савремене цивилизације, његове су функције усмерене на здравље и развој социјалних, културних и образовних аспеката свих чланова друштва, нарочито деце.

Неспорно је да ЕУ, њене чланице, као и Република Србија раде на унапређивању и прилагођавању вредности спорта специфичним потребама деце. У периоду од 2000. године, започело се са активностима којима се препознају сви актери и чиниоци система спорта, како би се њихово пословање усавршило у корист непосредних корисника, пре свега, детета - спортисте, као и саме организације и функционисања спорта. У конкретним активностима се пошло од међународних докумената спортских и политичких организација као и академске заједнице, да би се временом усвајала и национална докумената, која су у Републици Србији представљена кроз Устав и легислативу (Закони о спорту), државне стратегије развоја спорта (2009 и 2014), акциони планови (планови за реализацију стратегија 2009. и 2013), правилници, кодекси, као и одлука Националног просветног савета.

Академска заједница физичког васпитања дала је подстицај хуманом свету дечијег одрастања кроз спорт, тако што је у својим акредитованим студијским програмима укључила предмет „Дечији спорт“. Како и приличи, за овај предмет је припремљен уџбенички материјал - научна монографија „Дечији спорт од праксе до академске области“.

Циљ удружене активности система спорта, државе и академскезаједнице физичког васпитања и спорта је обезбеђивање хуманог света дечијег 
спорта - уважавање његове специфичности и принципа рада, на који се не могу преносити обрасци рада са одраслима. Одређена је визија, именовани су циљеви, задаци и исходи, усвојена су документа, припремљени пратећи писани материјали који се тичу предмета и проблема дечијег спорта. Тим и таквим сазнајним приступом, сачињени су темељи дечијег спорта који треба да прерасту у принципе стручног рада у јединственом васпитно-образовном подручју Дечији спорт и који треба да обезбеде:

- разумевање потребе и обезбеђивање права детета, доношење стручних и правних норми и докумената у области дечијег спорта;

- специфичност организовања дечијег спорта као подсистема спорта и образовања, али и индивидуалних интересовања детета са елементима, као што су управљање, финансирање, организација клубова, тренажних центара;

- формирање квалитативних критеријума за (а) организацију система тренинга, (б) развој младих спортиста;

- здравствену бригу и заштиту, њихово континуирано праћење, навике у исхрани, превенција од повреда;

- превенцију у допингу, заштита малолетника од свих врста насиља и злостављања;

\section{ЛИТЕРАТУРА}

1. Бачанац љ, Петровић Н, и Манојловић $\mathrm{H}$. (2010). Психолошке основе тренирања младих cпортиста. Републички завод за спорт. Београд

2. Бачанац, Љ. и Радовановић, И. (2005). Bаспитање кроз спорт. Учитељски факултет у Београду.

3. Дечији спорт од праксе до академске области (2010). Факултет спорта и физичког васпитања, Београд.

4. Јевтић, Б., Радојевић, Ј., Јухас, И. и Ропрет, Р. (2010) Дечији спорт од праксе до академске области. У Б. Јевтић, Ј. Радојевић, И. Јухас, Р. Ропрет Ед „Дечији спорт од праксе до академске области“ стр. 19-27. Факултет спорта и физичког васпитања, Београд.
- поштовање принципа тренинга сходно биолошкој, хронолошкој и спортској „старости“ детета (обим, интензитет тренинга, заједнички тренинг девојчица и дечака);

- образовање спортиста, организација спе= цијализованих школа и одељења, веза између спорта и професионалне каријере, стипендије, програми након завршетка каријере;

- регулисање права младих спортиста, права из уговорног односа спортиста - клуб савез, право на мобилност, компензација за први клуб, социјално и пензионо осигурање;

- програме оспособљавања и усавршавања тренера;

- програм рада са децом са хендикепом и децом са посебним потребама у васпитно образовном раду.

Афирмација дечијег спорта је најбољи начин функционисања друштва 21. века за интегрални развој деце, њихов позитиван биолошки, социјални, афективни и интелектуални развој, за прихватање вредности, као што су труд, поштовање, солидарност, поверење, коегзистенција и социјална кохезија, етничка, полна и верска толеранција.

5. Jevtić, B. (2018). Olimpizam i studentski sport. U E. Kastratovic (ed): U duhu Olimpizma (str.1547). Fakultet za biznis i pravo, Beograd.

6. Merkel, L.D. (2013). Youth sport: positive and negative impact on young athletes. Open Access Journal of Sports Medicine: 4 151-160

7. Petru K, Froberg K, Madela A, \& Tokarski W. (2008). Higher education in sport in Europe. UK: Mayer \& Mayer sport.

\section{Документа:}

1. European Commission (2008). Study on training of young sportsmen/women in Europe. INEUM consulting, June 2008. 
2. The Helsinki Report on Sport - COM (1999) 644, Report from the Commission to the European Council with a view to safeguarding current sports structures and maintaining the social function of sportwithintheCommunity framework,1.12.1999., Retrieved 1.2.2018. from http://eurlex.europa.eu/LexUriServ/LexUriServ. do? uri=COM:1999:0644:FIN: EN:PDF

3. Treaty of Amsterdam, OJ C 340, 10.11.1997., The Declaration on Sport, Retrieved 1.2.2018. from http://europa.eu.int/eurlex/lex/en/ treaties/ dat/11997D/htm/11997D.html

4. Treaty of Lisbon, OJ C 306, 17.12.2007, Retrieved 1.2.2018. from https://eur-lex.europa.eu/legalcontent/EN/ALL/?uri=OJ\%3AC\%3A2007\%3A30 $6 \% 3 \mathrm{ATOC}$

5. Treaty of Nice, OJ C 80, 10.3.2001, Retrieved 1.2.2018. from https://eur-lex.europa.eu/legalcontent/EN/ALL/?uri=OJ\%3AC\%3A2001\%3A08 $0 \% 3 \mathrm{ATOC}$

6. White paper on sport, Commission of the European Communities, Brussel, 11.7.2007, COM (2007) 391 Final, Retrieved 1.2.2018. from http://eur-lex.europa.eu/legal-content/EN/ TXT/?uri=CELEX\%3A52007DC0391

7. Акциони план развоја спорта 2014-2018 („Сл. гласник РС“, бр. 1/2015).

8. Закон о спорту („Сл. гласник РС“, бр. 10/2016).

9. Закон о спорту („Сл. гласник РС” бр. 24/11).

10. Закон о спорту („Службени гласник РС», бр. $52 / 96$ ).

11. Јевтић, Б. (2006). Идејни оквир новог систем спорта Републике Србије. Заједничка седница чинилаца система спорта Србије. Документ ОКС.

12. Министарство омладине и спорта (2009). Акциони план за спровођење Националне Стратегије развоја спорта у Републици Србији (2009 - 2013). Доступно 1.2.2018. на www.mos. gov.rs.

13. Национални просвени савет Републике Србије (2012). Предлог мера за унапређивање наставе физичког васпитања. (доступно 15.1.2018. нa http://www.nps.gov.rs/).
14. Необјављени материјали Југословенског олимпијског комитета (Материјал др Мадић Дејана - са 11. састанка радне групе Европских невладиних спортских организација ЕНГСО, 2001).

15. Одлука о образовању Националног савета за борбу против насиља и недоличног понашања гледалаца на спортским приредбама («Службени гласник РС», бр. 65/11 и 100/12).

16. Правилник о ближим условима за обављање спортских активности и спортских делатности («Службени гласник РС», број 17/13).

17. Правилник о дозволи за рад спортских стручњака («Службени гласник РС», бр. 7/13).

18. Правилник о надзору над стручним радом у области спорта («Службени гласник РС», бр. 92/11);

19. Правилник о спортским гранама од посебног значаја за Републику Србију («Службени гласник РС», 6р. 72/11 и 25/13).

20. Правилник о условима за обављање спортских делатности («Службени гласник РС», бр. $63 / 13)$.

21. Правилник о утврђивању здравствене способности спортиста за обављање спортских активности и учествовање на спортским такмичењима («Службени гласник PC», 6p. 15/12).

22. Републички завод за спорт (2010). Анализа реализације акционог плана стратегије развоја спорта републике Србије (доступно 25.2.2018 на http://www.rzsport.gov.rs/download/file/ EVALUACIJA\%20STRATEGIJE\%2020092010\%20ex.pdf)

23. Стратегија развоја спорта 2014-2018 („Сл. гласник РС“, бр. 1/2015).

24. Стратегија развоја спорта у републици Србији за период 2009-2013 („Сл. гласник РС“, бр. $110 / 2008)$.

25. Устав Републике Србије („Сл. гласник РС“, бр. 98/2006). 